DOES STATE OWNERSHIP HURT OR HELP MINORITY SHAREHOLDERS?

INTERNATIONAL EVIDENCE FROM CONTROL BLOCK ACQUISITIONS

\author{
PURSEY P.M.A.R. HEUGENS \\ Rotterdam School of Management \\ Erasmus University \\ Burgemeester Oudlaan 50 \\ Rotterdam, 3062 PA, The Netherlands \\ E-Mail: pheugens@,rsm.nl \\ STEVE SAUERWALD * \\ Department of Managerial Studies \\ University of Illinois at Chicago \\ 601 South Morgan Street, 2210 University Hall \\ Chicago, IL 60607-1722, USA \\ E-Mail: ssauerw@uic.edu
}

\title{
ROXANA TURTUREA
}

Aalto University

School of Science

Maarintie 8

02150, Espoo, Finland

E-Mail: roxana.turturea@aalto.fi

\author{
MARC VAN ESSEN \\ Darla Moore School of Business \\ University of South Carolina \\ Columbus, SC, USA \\ E-Mail: Marc.Vanessen@moore.sc.edu \\ Emlyon Business School
}

* Corresponding Author

This article has been accepted for publication and undergone full peer review but has not been through the copyediting, typesetting, pagination and proofreading process which may lead to differences between this version and the Version of Record. Please cite this article as doi: $10.1002 /$ gsj.1337 
Running Title: Does state ownership hurt or help minority shareholders?

Keywords: Control transactions; legal institutions; political institutions, private benefits of control, state ownership. 


\section{DOES STATE OWNERSHIP HURT OR HELP MINORITY SHAREHOLDERS? INTERNATIONAL EVIDENCE FROM CONTROL BLOCK ACQUISITIONS}

\section{RESEARCH SUMMARY}

We argue that state ownership is a crucial policy instrument for alleviating what is perhaps the most important principal-principal (PP) agency problem around the globe: private benefits of control $(\mathrm{PBC})$. Our results illustrate that states reduce $\mathrm{PBC}$ in the companies in which they acquire controlling ownership positions. We also examine how legal and political institutions influence the extent to which states accomplish this goal. Anti-self-dealing legal regulations make states more effective in their efforts to constrain PBC, while political constraints make them less effective. Regimes with high state capacity appear not to prioritize PBC reduction. We test and corroborate these ideas in a sample of 1,354 control transactions across 54 countries.

\section{MANAGERIAL SUMMARY}

The one-sided appropriation of wealth by dominant owners is arguably the biggest threat to minority shareholders around the globe. An important question that has thus far remained unaddressed is whether state ownership of firms increases or decreases the extraction of these socalled private benefits of control. By investigating a large number of transactions involving the transfer of corporate control in 54 countries, we find that state acquirers of controlling ownership positions generally respect minority shareholder rights more than other types of new controlling shareholders. This effect is stronger in countries with strong legal protection of minority shareholders. However, political constraints make it more challenging for state acquirers to keep PBC in check while "strong" states may (mis)use the firms they invest in as policy vehicles. 


\section{INTRODUCTION}

State capitalism is on the rise across the globe (Bruton et al., 2015; Guillén \& Capron, 2016; Inoue, Lazzarini, \& Musacchio, 2013; Wood \& Wright, 2015). After decades of privatization, in which states reduced their involvement in the corporate sector (Filatotchev, Buck, \& Zhukov, 2000; Vaaler \& Schrage, 2009), governments are now again becoming more actively involved in corporations (Musacchio \& Lazzarini, 2014). For instance, state-owned enterprises (SOEs) were involved in 9 of the 15 largest IPOs between 2005 and 2012, represented 10\% of global GDP in 2010, and grossed \$3.6 trillion in sales in 2011 (The Economist, 2012a).

These developments entail more than a pendulum swing, as state ownership itself has changed dramatically over the years (Grosman, Okhmatovskiy, \& Wright, 2016). SOEs used to be owned by the state in their entirety (Megginson \& Netter, 2001), but recently states have begun to work side-by-side with private investors in mixed enterprises not previously government-linked (Bruton et al., 2015; Liu, Beirne, \& Sun, 2015; Musacchio \& Lazzarini, 2014; Shi, Hoskisson, \& Zhang, 2016). Overall, it seems that states increasingly engage with private corporations for strategic reasons, rather than for bailing out corporations in financial distress (Musacchio, Lazzarini, \& Aguilera, 2015; Rudy, Miller, \& Wang, 2016; Stephan, Uhlaner, \& Stride, 2015).

What these accounts of state involvement fail to explain, however, is what role states play in corporate governance in general and what it entails for the position of minority shareholders in particular (van Essen, van Oosterhout, \& Heugens, 2013; Young et al., 2008). Corporate 
governance theory is focused on securing the interests of minority shareholders by reducing agency conflicts (Guillén \& Capron, 2016; La Porta et al., 1998). Agency problems may derive from principal-agent (PA) agency conflicts when managers prioritize their self-interest over shareholder objectives (Jensen \& Meckling, 1976). State ownership is rarely effective at constraining these PA agency problems due to the low monitoring incentives of state shareholders compared to those of private shareholders (Peng et al., 2016). Another type of agency problem derives from principal-principal (PP) agency conflicts, involving situations in which controlling shareholders expropriate minority shareholders (Young et al., 2008). While this problem likely outweighs PA problems in terms of material consequences for minority shareholders (Young et al., 2008), we currently have an insufficient understanding of how state acquisitions of controlling ownership positions affect PP agency conflicts.

PP conflicts often materialize in the form of private benefits of control (PBC). PBC are private returns that controlling shareholders appropriate in excess of their ownership rights. $\mathrm{PBC}$ do not only affect minority shareholders, but also firm performance by increasing borrowing costs (Lin et al., 2018). We theorize that when states become controlling shareholders, they have comparatively stronger incentives to refrain from extracting $\mathrm{PBC}$ than when private parties become controlling shareholders. The reason for this is that states feel the long-term consequences of $\mathrm{PBC}$ extraction more severely whereas the "expropriation of minority shareholders does not imply any costs for [private] controlling shareholders" (Filatotchev et al., 2001, p. 303). Specifically, PBC extraction negatively impacts the long-term functioning and 
performance of the nation state. For instance, PBC may hamper the development of financial markets and complicate the political process by shifting control over the economy to oligarchs and business elites (Morck, Wolfenzon, \& Yeung, 2005).

We furthermore consider three institutional contingencies to understand the mechanisms through which state ownership affects PBC extraction. First, we investigate the moderating role of legal institutions designed to protect minority shareholders against self-dealing transactions. State ownership traditionally is considered a strategic liability (Shleifer \& Vishny, 1994), causing agency problems (Peng et al., 2016) and the pursuit of political (Shleifer \& Vishny, 1998) or social objectives over economic goals (Bai \& Xu, 2005). We predict that when state acquirers use both ownership and regulation against self-dealing, they exhibit an even stronger commitment to the goal of reducing $\mathrm{PBC}$ and will create an environment where state owners are less tempted to extract PBC themselves. Second, we scrutinize political institutions that constrain government discretion (Bortolotti, Cambini, \& Rondi, 2013; Henisz, 2000). While political constraints are often considered favorable in terms of creating stable political environments, we predict that political constraints increase $\mathrm{PBC}$ consumption by state acquirers because it lowers the ability of governments to engage swiftly and unanimously in the governance of mixed ownership firms. Third, we theorize the effects of state capacity as another important political institution on the tendency of state acquirers to extract PBC (Guillén \& Capron, 2016; Hanson, 2014). State capacity captures a state's ability to realize its political ambitions and enforce its policy objectives efficiently. While a basic level of state capacity is necessary for addressing 
PBC, we argue that high-capacity states are powerful enough to pursue policy objectives important to the state and its many stakeholders instead of the goals and objectives of for-profit firms and its minority shareholders.

We test our ideas in a sample of 54 countries to address the lack of international state capitalism research (Bruton et al., 2015) and to highlight the role of the state as an important yet understudied actor in corporate governance (Aguilera \& Jackson, 2003). We use control transaction premiums to estimate the level of PBC captured by controlling owners (Albuquerque \& Schroth, 2010, 2015; Dyck \& Zingales, 2004). These premiums measure the amount of private benefits expected after the private acquisition of a controlling block of shares is completed (Barclay \& Holderness, 1989; Dyck \& Zingales, 2004). While control transaction premiums are the conventional way to assess $\mathrm{PBC}$, some studies have gauged PBC by computing dual-class voting premiums (Nenova, 2003; Zingales, 1994). The benefit of using control transaction premiums is that it allows us to cover a larger and more representative international sample, as dual-class shares are illegal in many countries. New controlling owners can be either the state (i.e., state acquirer) or a private party (i.e., private acquirer). Our sample consists of 1,354 control transactions, making it about three times larger than the landmark study by Dyck and Zingales (2004), which involved 393 transactions.

We make two contributions with our work. First, we contribute to the corporate governance literature by shedding new light on the strategic role of the state in corporate governance (Bruton et al., 2015). Specifically, we show that states actively intervene in the 
governance of firms to minimize $\mathrm{PBC}$ when they acquire a controlling stake in firms not previously government-linked. Whereas state ownership is frequently seen as a source of agency problems in its own right, we argue that a complementary stewardship perspective is necessary to fully understand the reasons for state involvement in corporate governance.

Second, we contribute to international business research by exploring the institutional contingencies that affect state acquirers' ability to curtail PBC from an international comparative perspective. Whereas prior studies have stressed the direct effects of macro-level institutions on corporate outcomes, we show that institutional effects frequently operate by either supporting or inhibiting the ability of the state to intervene at the micro-level (Jackson, 2010; van Essen et al., 2012). Our findings show that country-level institutions have a powerful influence on the motivation and ability of state acquirers to curb PBC. Specifically, we show that legal institutions that protect minority investors reduce the "liabilities of state ownership" by making SOEs more transparent and accountable. In contrast, political constraints and state capacity decrease the ability of state acquirers to reduce PBC (cf. Lazzarini, 2015).

\section{THEORY AND HYPOTHESES}

\section{Private benefits of control}

$\mathrm{PBC}$ are returns that controlling shareholders appropriate privately in excess of their cash flow rights (Dharwadkar, George, \& Brandes, 2000; Dyck \& Zingales, 2004; Sauerwald \& Peng, 2013; Young et al., 2008). While some PBC are "not necessarily inefficient" (Dyck \& Zingales, 2004, p. 541) because they compensate controlling shareholders for private monitoring and 
advice (Gilson \& Schwartz, 2013), corporate governance scholars generally concur that PBC signal the presence of PP agency problems occurring between controlling and minority shareholders (La Porta, Lopez-de-Silanes, \& Shleifer, 1999; Li \& Qian, 2013; Sun, Hu, \& Hillman, 2016; Villalonga \& Amit, 2006). If control is privately valuable, the purchase of an equity stake large enough to gain control can be used to estimate the value of PBC (Dyck \& Zingales, 2004). The root cause of substantial PBC is thus a conflict of interests between controlling and non-controlling shareholders (Li \& Qian, 2013; Singla, Veliyath, \& George, 2014; Young et al., 2008).

PBC tend to be an important governance concern when controlling shareholders are present in the firm (La Porta et al., 1999; Peng \& Sauerwald, 2013; Young et al., 2008), since they are able to influence firm decision making (La Porta et al., 1999). Controlling ownership structures are commonplace not only in Asia (Claessens et al., 2002), Latin America (Céspedes, González, \& Molina, 2010), and continental Europe (Faccio \& Lang, 2002; van Essen et al., 2013), but also in the U.S. (Dalton et al., 2003; Holderness, 2009) and the U.K. (Franks, Mayer, \& Rossi, 2009). PBC materialize when controlling shareholders use their influence in the firm to initiate self-benefiting transactions, allowing them to appropriate wealth from non-controlling shareholders (Djankov et al., 2008; Enriques, 2000).

Prior studies have documented that such transactions may take different forms. First, controlling shareholders or their representatives may "tunnel" corporate resources out of the firm by entering into contracts with other entities they control, using transfer prices that are 
substantially lower than the market value of these resources (Johnson et al., 2000). Second, entrenched insiders may reduce firm risk because they receive nonpecuniary private benefits such as socioemotional wealth from managing and controlling the firm (Gomez-Mejia, LarrazaKintana, \& Makri, 2003). Third, controlling shareholders may transfer losses occurring in some of their ventures to highly profitable corporations in the same business group to lower corporate tax burdens (Conac, Enriques, \& Gelter, 2007). Fourth, entrenched insiders may prevent valuecreating corporate control changes in order to perpetuate their position of influence, which denies minority owners increases in shareholder wealth (Li \& Qian, 2013).

PBC can further be illustrated by a practical example, namely that of the group of companies controlled by the Mexican business leader Carlos Slim (e.g., see The Economist, 2004, 2008, 2012b, 2013a, 2014a). Mr. Slim has the potential to appropriate PBC from exercising his control rights in these companies in at least four different ways. First, he can privately acquire local or foreign companies (as has happened in the past with corporations such as Cigatam, Hershey Mexico, and Reynolds Aluminum Mexico), and proceed to sell them to a business group he owns partly, but controls completely (in this case Grupo Carso) at a premium price. Second, he may sell the outputs of firms he owns partly but controls completely (e.g., Cigatam's cigarettes or Hershey Mexico's confectionary items) at a discounted price to a retail firm he owns completely (such as Grupo Sanborns). Third, he can pay himself or his close associates salaries or consulting fees for services rendered to firms he owns partly but controls completely (such as the telecommunications firms América Móvil and Telcel). Fourth, he may 
retain the profits generated by companies he owns partly but controls completely in share buyback funds, which serve to bolster the value of shares in the hands of insiders (e.g., America Movil recently increased the reserves in its buyback fund from 30 to 35 billion pesos; Reuters (2015)). Importantly, each of these transactions is legal under Mexican law (The Economist, 2012b, 2013a).

Traditionally, law and finance scholars have proposed to solve the problems created by PBC through legal institutional remedies (La Porta et al., 1998). The argument is that legal institutions constrain corporate insiders by enforcing strict shareholder rights (Guillén \& Capron, 2016; La Porta et al., 1998) and support efficient contracting between minority and controlling shareholders by reducing information asymmetries (Djankov et al., 2008). Yet, the law and finance literature has often assumed that legal institutions alone are a sufficient remedy for constraining PBC (Dyck \& Zingales, 2004), and has thus limited itself to an analysis of the indirect, regulatory role of the state in corporate governance (La Porta et al., 1998). This onesided attention has left the direct participation of the state in corporate governance through its active role as a controlling owner largely untheorized and untested.

\section{State ownership and PBC}

States may be able to influence $\mathrm{PBC}$ by acquiring a controlling ownership stake in firms (Carvalhal da Silva \& Subrahmanyam, 2007). A controlling ownership position allows controlling shareholders the opportunity to implement their interests (Holderness, 2009). One line of argument suggests that states become involved in firms through ownership specifically to 
extract $\mathrm{PBC}$, as previous research has characterized SOEs as pursing personal, political, and social goals (Megginson \& Netter, 2001; Shleifer \& Vishny, 1998). First, when politicians exercise the power of a controlling shareholder, they may capture private benefits by engaging in related-party transactions or directly expropriate resources (Fan, Wong, \& Zhang, 2007; Shleifer \& Vishny, 1994). Second, states may use firms to pursue political objectives (Shleifer \& Vishny, 1998). These PBC may derive from diverting resources from SOEs to political allies, such as favored industries (Claessens, Feijen, \& Laeven, 2008) or creating employment opportunities for loyal supporters (Dinc \& Gupta, 2011). Third, states may prioritize social objectives, such as high employment levels (Bai \& Xu, 2005). This is especially crucial when the pressure on states to maintain social order is high, such as during recessions (Musacchio \& Lazzarini, 2014). Pursuing social objectives by states is not automatically detrimental for the society overall, as it may help lower crime, unemployment, and poverty. However, when this social agenda is implemented via SOEs, it involves direct costs for minority shareholders. Lastly, state controlling owners are also often ineffective monitors because bureaucrats lack expertise (Dharwadkar et al., 2000), monitoring duties among bureaucrats are dispersed across multiple regulatory agencies (Zou \& Adams, 2008), and low-powered incentives such as fixed salaries are commonplace among SOE managers (Cull \& Xu, 2005). This lack of effective monitoring could result in other stakeholders extracting PBC themselves while the state controlling owner is unable to prevent such value expropriation. 
Nonetheless, the motives of the state for acquiring controlling ownership positions may be more geared towards limiting PBC than previously thought. State ownership has transformed considerably over time, leading to new varieties of state ownership in which states and private investors work side-by-side (Bruton et al., 2015; Grosman et al., 2016; Musacchio \& Lazzarini, 2014). These new varieties of state ownership differ from SOEs in which the state is the sole shareholder (Megginson \& Netter, 2001). Many new SOEs with hybrid or partial state ownership structures are not the result of partial privatization, through which states sell off an equity stake in an existing SOE to private investors, but the outcome of partial nationalization, through which states buy stocks in non-SOEs. Partial state ownership has been found to improve firm performance (Gupta, 2005; Inoue et al., 2013), whereas traditional SOEs have a solid track record of underperformance (Megginson \& Netter, 2001; The Economist, 2014b). Therefore, state acquirers may refrain from extracting PBC simply because they want to avoid engaging in actions that could harm firm performance, and consequently diminish the market value of their own equity stake. This is particularly true because state owners are typically long-term (or patient) owners that would be hurt by declines in the market value of their investments.

Besides direct performance considerations, the state may also be motivated to reduce principal-principal agency conflicts. The most immediate "victims" of substantial PBC levels in firms with concentrated ownership are minority shareholders, as these parties will have their wealth siphoned off (Young et al., 2008). While governments may refrain from consuming PBC because they see minority shareholder protection as an important policy goal in itself (La Porta et 
al., 1998), PBC have more invasive consequences for the policy goals of the state that extend beyond the interests of minority shareholders. For instance, PBC signal economic entrenchment in the national economy (Morck et al., 2005), which hinders the development of effective financial markets (Acemoglu \& Robinson, 2012; Peng, 2003). PBC may also lead to higher degrees of income inequality if the returns from economic activities are distributed to political allies and cronies (Beck, Demirgüç-Kunt, \& Levine, 2007). In other words, when the state refrains from extracting $\mathrm{PBC}$ through its ownership positions, this may be interpreted as a campaign for economic development (Acemoglu \& Robinson, 2012). States' attempts to reduce PBC thus do not merely benefit minority shareholders but a wide range of constituencies and a broad set of policy goals. By reducing PBC in the firms they control, states set an example of good practice for other companies to follow and clear the way for long-term economic success (Guillén \& Capron, 2016; Hanson \& Sigman, 2013).

By taking direct action, states can control PBC in three ways. First, states may appoint directors or executives to the firm, who will then promote change and discipline from within. For instance, Li and Qian (2013) show that CEOs with political connections are more likely to approve value-creating acquisitions, because politically connected CEOs are interested in advancing their political careers by supporting the goals of minority shareholders and society at large. Furthermore, Lin and Germain show that new generations of state-appointed managers in China infuse SOEs with effective management systems such as detailed work standards and comprehensive appraisal systems, thereby breaking the management style of previously 
entrenched insiders, which frequently "lacked specificity, enforceability, and comprehensiveness" (2003, p. 1136). By acting as inside monitors, it becomes easier for states to reduce information asymmetries with entrenched insiders and to "curb rent seeking through a careful process of policy evaluation" (Lazzarini, 2015, p. 105). In sum, appointing internal agents is an important instrument through which states curtail PBC, allowing them to directly influence the monitoring and review capabilities of the firms they control.

Second, states may aid the firm by infusing it with dedicated governance competencies (Inoue et al., 2013; Lazzarini, 2015). States often encourage and contribute to the development of managerial talent which, in turn, lends targeted support in the areas of general administration, performance management, and fiscal issues (Aivazian, Ge, \& Qiu, 2005). For instance, competent state bureaucrats may push for infrastructure support and investment incentives in Chinese SOEs (Park, Li, \& Tse, 2006) and bureaucrats in Brazil have supported SOEs with patient capital and legitimacy spillovers (Inoue et al., 2013). This type of support from the state makes it easier for executives to detect and address unfair third-party transactions and is especially useful when the firm's current management suffers from competency deficiencies (Hendry, 2002) or has been appointed for symbolic reasons (Peng, 2004). Research from Brazil shows that SOEs enjoy better corporate governance practices than non-SOEs: they have higher scores on an established corporate governance index, have proportionately fewer non-voting shares, and are more frequently cross-listed in the U.S. Consequently, PBC are lower in Brazilian SOEs than in non-SOEs (Carvalhal da Silva \& Subrahmanyam, 2007). 
Third, states can also combat $\mathrm{PBC}$ by bringing types of policing and sanctioning powers to bear on SOEs to which private shareholders simply have no recourse. States can use the power vested in anti-corruption authorities as an instrument against PBC. An example is Chinese president Xi Jinping's vow to fight both the "tigers" and "flies" (i.e., high- and low-ranking officials and insiders) involved in self-benefiting transactions in SOEs through the anticorruption office of the Chinese Communist Party (The Economist, 2013b, 2014c). States can thus resort to "gunboat diplomacy" tactics (Duanmu, 2014), preventing expropriation by insiders by invoking the sanctioning powers of their anti-corruption apparatuses. In sum, we expect that states will be motivated to reduce PBC in the firms they control, and will also have several compelling ways to do so. Thus,

Hypothesis 1: In firms in which the state acquires a controlling ownership position, private benefits of control (PBC) will be lower.

\section{The contingency effect of anti-self-dealing laws}

PBC are prevalent in related-party transactions when insiders engage in self-dealing (Gilson, 2006) or tunneling (Johnson et al., 2000) at the expense of minority shareholders (Djankov et al., 2008). States can combat the PBC resulting from such transactions by issuing regulations that constrain the ability of insiders to privately benefit from related-party transactions (Shleifer, 2010). These regulations empower minority shareholders to address PBC through the private enforcement of their rights (Bebchuk, 2005), rather than through state-initiated enforcements such as fines (Liu \& Magnan, 2011). Prior studies have shown that anti-self-dealing regulations 
help to alleviate $\mathrm{PBC}$ concerns among minority shareholders. In China, for example, rates of corporate investment are higher in regions in which investors are less concerned about expropriation by entrenched insiders (Liu \& Siu, 2012).

While anti-self-dealing laws have been proven useful to reduce PBC overall, they can be particularly helpful to decrease PBC in firms with state ownership further. First, while state ownership should reduce PBC overall, SOEs are often exposed to a "liability of stateness" (Bruton et al., 2015; Musacchio et al., 2015). State managers and directors may lack highpowered incentives to monitor and advise firms (Bruton et al., 2015; Dharwadkar et al., 2000). SOEs may also be subject to the influence of politicians, who may use corporate resources to advance their party's interests or to pursue policies that are likely to get them reelected (Musacchio et al., 2015). SOEs may also pursue social goals such as high employment at the expense of firm profitability (Bai \& Xu, 2005). All of these issues are related to a lack of external oversight over SOEs. Specifically, SOEs have been described as "opaque" and as operating behind closed doors (Musacchio et al., 2015, p. 126), which may provide opportunities to further the goals of the political elite at the expense of the general public (Shughart \& Razzolini, 2003). It may therefore be useful for governments to create an institutional setting that opens up the SOEs and prevents negative government interference. Governments that "selfcommit" to transparency provide "credible mechanisms to monitor the outcomes of policies that curb dysfunctional political interference" (Musacchio et al., 2015, p. 126). We therefore expect 
that stricter ex-ante anti-self-dealing laws help to reduce the liability of stateness in SOEs, and consequently reduce $\mathrm{PBC}$.

Second, when states self-commit to not extract PBC themselves, it does not automatically mean that their appointed representatives in SOEs can prevent other firm insiders from extracting PBC. While these appointed representatives may be competent and well intentioned, they may require additional institutional support to deter other firm insiders from extracting PBC. Therefore, states may opt to issue laws that provide these technocrats with the necessary instruments to intervene when they observe self-dealing in the firms they administer. This has the additional benefit of making anti-self-dealing laws more actionable by combining them with insider monitoring. For example, in China, after passing a regulation in 2001 (the "Solutions for Listed Firm Checks" regulation) that made monitoring against self-dealing transactions easier by pushing for more transparent and universal information disclosure amongst all listed firms, regulatory enforcements against self-dealing transactions increased. Interestingly, however, this effect was primarily observed in SOEs, and the likelihood of regulatory enforcement increased with the percentage of state ownership (Hou \& Moore, 2011). We therefore expect ex-ante country-level laws promoting transparency and participation to strengthen the PBC-reducing effect of state ownership. Thus,

Hypothesis 2: The negative relationship between state acquirer and private benefits of control (PBC) will be stronger in countries characterized by stricter (ex-ante) anti-selfdealing laws. 


\section{The contingency effect of political constraints}

Political institutions may be an important contingency condition on the state's ability to affect PBC. Political institutions are the "rules of the game" that constrain the choices of political actors, including elected officials and appointed bureaucrats (March \& Olsen, 1989). Political constraints are an important political institution that reduces the policy discretion of political actors by separating political powers, thus creating a system of countervailing powers (Henisz, 2000). The literature identifies several positive effects of these constraints. For instance, they ensure political stability, providing "credible political commitments" that lead to long-term investments in the local economy (Garcia-Canal \& Guillén, 2008; Henisz, 2000; Holburn \& Zelner, 2010; Slangen, 2013). Constraints in the political system also make it challenging for firms to gain political influence as many political actors must be convinced or compensated. Yet, politically constraining the state has downsides. Political constraints slow down the political process and may drive domestic companies to invest in more dynamic foreign contexts (Witt \& Lewin, 2007). Political constraints also hinder privatizations because of the public costs faced by politicians (Bortolotti \& Pinotti, 2008; Boubakri et al., 2011).

In relation to the position of minority shareholders and in terms of the state's involvement in corporate governance, we suggest that state acquirers reduce PBC to a lesser degree when political constraints are high for three reasons. First, when state controlling owners engage in behaviors that harm minority shareholders, this is usually achieved by a "team effort". For instance, in the recent Petrobras scandal in Brazil, the documented value of expropriation efforts 
surpassed the limits of "classic" forms of PBC extraction and included systematic bribery. Several dozen politicians from multiple parties are being investigated, including several topranked officials such as a former president of Brazil. High political constraints imply greater political fragmentation in the political process, which provides more political factions with opportunities to extract PBC from state-owned corporations. This allows more "grabbing hands" to divert resources to political or social causes that may not be in the interest of minority shareholders. Moreover, splitting political responsibility between numerous parties may result in insufficient incentives for any party to bear the costs of monitoring in the firm (Edmans \& Manso, 2011). In contrast, if political fragmentation is low, governments are responsible to fewer political constituents that may ask for political and social favors.

Second, the political fragmentation entailed by high political constraints makes it more difficult to reach consensus on state policies, including those aimed at PBC reduction (Morck et al., 2005). Political parties with different ideologies may vary in their preferences regarding SOEs in general, and the issue of PBC extraction in SOEs in particular. On the other hand, SOEs may refrain from PBC extraction and channel their efforts towards the narrow goals of the firm and well-defined policy objectives when political constraints are low. It has been argued that a simple corporate objective improves the management and value of corporations (Jensen, 2002; Sundaram \& Inkpen, 2004). Yet, it is challenging to have clear objectives when the political process is fragmented in high political constraint contexts. 
Lastly, high political constraints could lower the ability of the state to intervene in SOEs to ensure alignment with the policy goals of the state. Insiders may take advantage of the restricted political discretion associated with high political constraints to pursue their own personal agenda. While controlling owners have been regarded as the main beneficiaries of PBC, managers and other firm insiders can step up to extract PBC themselves, particularly when the state controlling owner is a silent partner. In contrast, when political constraints are low, insiders may refrain from extracting $\mathrm{PBC}$ because they do not want to risk antagonizing a state owner that can respond swiftly and effectively. Overall, the $\mathrm{PBC}$ reducing effects of state acquirers may be reduced if the government is too constrained to effectively monitor and influence firms (Bortolotti et al., 2013). Overall, we predict:

Hypothesis 3: The negative relationship between state acquirers and private benefits of control (PBC) will be weaker in countries characterized by more political constraints.

\section{The contingency effect of state capacity}

Besides constraints on political actors, another important political institution that may influence a state refraining from extracting PBC is state capacity (Guillén \& Capron, 2016; Hanson, 2014).

State capacity captures a state's ability to enforce its policy objectives. It is an important precondition for nation building (Acemoglu, Moscona, \& Robinson, 2016) and jumpstarting the development process in emerging economies (Hanson, 2014). While a "strong" and capable state clearly has many benefits, a fundamental political dilemma is to balance and countervail this influence, because a strong government "is also strong enough to confiscate the wealth of its 
citizens" (Weingast, 1995, p. 1). This argument mirrors findings from the corporate governance literature: powerful shareholders can not only help minority investors (Shleifer \& Vishny, 1986), but may also entrench and corrupt themselves (Morck, Shleifer, \& Vishny, 1988).

In the context of constraining $\mathrm{PBC}$, high state capacity may increase the $\mathrm{PBC}$ consumption of state acquirers, notably when states use the companies they acquire to pursue policy goals important to the state and its many stakeholders. First, state capacity increases the power of the state (Hanson \& Sigman, 2013). Powerful states have the ability to insulate the state apparatus from outside influences (Fourcade, 2009). For instance, Guillén and Capron (2016) show that high capacity states are less likely to follow the calls from important stakeholder groups to improve minority shareholder rights in their countries. Leadership studies similarly find that powerful actors often resist calls for strategic change (Golden \& Zajac, 2001; Hambrick \& Fukutomi, 1991). Similarly, powerful state acquirers may resist the pursuit of minority shareholder objectives when they transition into a controlling ownership position. This is because powerful states may continue to rely on an established state logic that prioritizes the policy objectives of the state and its many stakeholders. On the other hand, a less powerful state may be less capable of resisting calls from market participants and other shareholders to support market-oriented strategies that would benefit the company and its shareholders (Guillén \& Capron, 2016).

Second, state capacity may allow state owners to increase their power over firms beyond their nominal ownership stake. Firms with highly capable state owners may then be tempted to 
pursue social and political objectives, because the government now is better able to use the firm for its non-capitalist missions. On the other hand, if the state is less powerful, it may be unable to extract private benefits for political cronies as well as for political and social missions (Morck et al., 2005). For instance, government bureaucrats managing the business may lack incentives to implement the policy goals of the government in low capacity states. Overall, we suggest:

Hypothesis 4: The negative relationship between state acquirers and private benefits of control (PBC) will be weaker in countries characterized by more capable states.

\section{METHODS}

\section{Sample}

We sampled public firms from around the world with private control transactions taking place during the period 1990 to 2017. We relied on the Securities Data Company (SDC) international mergers and acquisitions database (Albuquerque \& Schroth, 2010; Dyck \& Zingales, 2004). We further restricted our sample to firms covered in Datastream to ensure that we are able to access public share prices. We complemented these two data sources with data on firm ownership from Thomson One Banker and firm annual reports. The specific selection of private control transactions followed Dyck and Zingales (2004).

First, for $\mathrm{PBC}$ to be observed, the transaction must convey control rights and attract attention from minority shareholders. Thus, we only considered equity transactions of 10 percent or larger to ensure sufficient market attention. In addition, we only considered transactions in which the acquirer held less than 20 percent in the target company prior to the transaction, but 
more than 20 percent as a result of it because shareholders of 20 percent or larger are typically considered controlling shareholders (Faccio \& Lang, 2002; La Porta et al., 1999, p. 476). From these transactions, we excluded spinoffs, recapitalizations, repurchases, acquisitions of remaining interest, and acquisitions by management (Dyck \& Zingales, 2004, p. 545), as these transactions do not involve a control transfer between two independent parties.

Second, we only selected transactions for which the private benefits are quantifiable. Thus, we excluded transactions for which the exchange share price and the size of the control block were not available. Additionally, we excluded transactions for which the share price for the control block could not be valued objectively (Dyck \& Zingales, 2004). This occurs in situations in which the transaction involves warrants, convertible bonds, notes, equity swaps, or options to buy additional shares (irrespective of whether options are exercised or not).

Lastly, we checked each control transaction by reading news stories in Lexis-Nexis to exclude transactions that did not actually transfer control blocks. This may be the case when two subsidiaries of the same parent company rearranged their cross-shareholdings. After screening SDC transactions based on all these criteria, we arrived at a comprehensive sample of 1,354 control transactions during the period 1990 to 2017 from 54 countries around the globe. In 67 of these transactions, the state was the acquirer of a controlling equity stake.

\section{Dependent variable}

Private benefits of control are measured by block premiums (Dyck \& Zingales, 2004). They are calculated as the price per share the acquirer paid for the control block (i.e., control price) minus 
the price per share on the stock exchange (i.e., market price) two days after the announcement of the control transaction. This difference is divided by the market price and multiplied by the proportion of cash flow rights conveyed by the control block.

PBC range from $-31 \%$ to $306 \%$ in our data. Additional data analysis suggested a positive skew in the data with "fatter tails" than a normal distribution. We therefore transformed PBC using the inverse hyperbolic sine (IHS) function first proposed by Johnson (1949):

$$
\sinh ^{-1}(\mathrm{x})=\log \left[\mathrm{x}+\left(\mathrm{x}^{2}+1\right)^{1 / 2}\right]
$$

This transformation is also known as "signed pseudo logarithm" because the distribution resembles $\operatorname{sign}(\mathrm{x}) * \log (|\mathrm{x}|)$. The regression coefficients can be interpreted similarly to $\log$ transformed dependent variables (Burbidge, Magee, \& Robb, 1988; Nyberg et al., 2010; Sauerwald, Lin, \& Peng, 2016). The IHS transformation usefully compresses ranges with extreme values, which allows the regression coefficients to represent the data and not a few extreme outliers.

Block premiums are measured at distinct points in time, which differs from more traditionally used acquisition premiums. Acquisition premiums measure the willingness of the acquirer to pay over the current market price, typically measured as control price minus the market price before the announcement of the control transaction (Hayward \& Hambrick, 1997). Our block premiums are measured after the announcement of the control transaction. This approach is better able to capture PP costs because it gives shareholders time to evaluate the intricacies of the control transaction. For instance, the ability to improve the competitive position 
of the firm due to synergies and improved management are more likely incorporated into the market price after the transaction was announced.

\section{Predictor variables}

State acquirer captures direct state involvement in corporate governance through firm ownership. It is measured via a binary variable taking the value " 1 " if the state bought a controlling stake sufficiently large to influence firm strategy (La Porta et al., 1999). This condition is met when the state accumulates at least 20 percent of outstanding shares, a measure previously used in corporate governance research (Faccio \& Lang, 2002). It is also consistent with prior research on state capitalism that finds that minority (i.e., less than 50 percent) state ownership positions yield considerable state influence (Inoue et al., 2013; Musacchio et al., 2015). It is worthwhile to mention that states sometimes use other legal entities to acquire stakes in target firms. For instance, the state acquirer may not only be the government of a country directly, but also a corporation that is ultimately controlled by the state. For the latter cases, we checked the shareholder information of all acquirers that were corporations in Thomson One Banker to determine if these corporations were ultimately state controlled or not.

Ex-ante anti-self-dealing laws in the home country of the target firm capture indirect state involvement in corporate governance through legal institutions aimed at preventing unfair related-party transactions in corporations. Consistent with previous studies (Bennedsen \& Nielsen, 2010; Fidrmuc, Korczak, \& Korczak, 2013; Gupta, Prakash, \& Rangan, 2013), it was measured via the "ex-ante control of self-dealing transactions" index developed by Djankov et al. 
(2008). Prior studies have also established that ex-ante self-dealing laws are the primary determinant of important economic outcomes, such as economic development (Haidar, 2009).

Political constraints in the home country of the target firm measure the feasibility of policy changes, or in other words, how changes in the preferences of any political actor leads to policy changes. This is accomplished by capturing the formal relationships among the branches of government (i.e., executive, legislative, and judicial) and the political composition of each branch. More political branches of government (e.g., two houses in the legislative branch, instead of just one house) and different political parties in each branch increase political constraints. We use the index developed by Henisz (2000), with values ranging from 0 to 1, where higher scores indicating more political constraints and thus less feasibility of policy change.

State capacity in the home country of the target firm captures the general ability of the state to implement its policy goals. State capacity does not measure the various policy objectives of states, but rather the extent to which states can effectively achieve them. State capacity is also independent from the political regime, meaning both democratic and autocratic states are able to develop and disseminate effective policies, and to manage their implementation (Fukuyama, 2013; Hanson \& Sigman, 2013). We use the state capacity index developed by Hanson and Sigman (2013), which is a measure used by recent studies because it entails a large coverage of countries and years (Guillén \& Capron, 2016). In addition, it accounts for the three main dimensions of state capacity (i.e., extractive, coercive, and administrative), whereas older measures tend to emphasize just one dimension (Fukuyama, 2013). 


\section{Control variables}

We controlled for several variables at the country, industry, target firm, and acquirer levels of analysis. At the country-level, we controlled for two variables measured in the home country of the target firm capturing the development of the economy and of the stock market (derived from the World Bank). First, we controlled for gross domestic product per capita (GDP/capita), defined as the total market value of all goods and services produced in a country divided by midyear population (in thousands of US dollars). Second, we controlled for stock market capitalization, defined as the market value of all publicly traded firms in the country (in trillions of dollars). It was included to control for an active takeover market in which a market for controlling blocks exists (Nicodano \& Sembenelli, 2004).

We also controlled for five formal and informal institutions in the home country of the target firm. First, cheating on taxes is a response to the World Values Survey (WVS) question “cheating on taxes if you have a chance is justified?" The variable was included to control for informal institutions that justify PBC at the expense of society at large (Dyck \& Zingales, 2004). Higher values indicate that tax violations are locally seen as morally justified. Second, freedom of press reflects the freedom of journalists and citizens in a country to express their opinions, as well as the state's protection of this freedom, according to Freedom House. This variable was included because the media is an important extralegal constraint on controlling shareholders (Dyck, Volchkova, \& Zingales, 2008). Third, rule of law may increase the effectiveness of governments by constraining governmental officials to only use their powers in ways prescribed 
by formal rules (Licht, Goldschmidt, \& Schwartz, 2007). We derived rule of law from Freedom House. Fourth, we account for the perception of the public that governmental officials do not exert public power for private gains. This variable measures control of corruption and was derived from the Worldwide Governance Indicators (WGI) (Kaufmann, Kraay, \& Mastruzzi, 2009). Finally, we controlled for ex-post anti-self-dealing laws to account for the ability of shareholders to sue controlling agents and hold them liable. This variable was derived from Djankov and his associates (2008).

We also controlled for characteristics of the target firm. First, we controlled for firm size, measured as the total sales of the target firm (in ten millions of US dollars). This variable was included because larger firms may allow the controlling shareholder or his/her agents to extract more PBC. Second, we account for $R \& D$ spending, operationalized as the amount of financial resources allocated to research and development efforts (in millions of US dollars). Third, financial leverage, measured as the ratio of total debt to common equity and expressed as percentage, is included because more slack resources may allow more PBC to be extracted. This and the previous variable R\&D spending are log transformed. Fourth, we included prior financial performance (measured as return on assets) because $\mathrm{PBC}$ are expected to be higher for high-performing firms, partly because the new controlling owner may be able to consume more perks and experience less severe monitoring from market intermediaries (Krause, Whitler, \& Semadeni, 2014). Fifth, we controlled for government sell-out, a dummy equal to 1 if a government is the legal entity that sells (part of) its shares in the control transaction. Sixth, we 
controlled for state minority control in target, a dummy variable equal to 1 if the state was a minority shareholder in the target before the transaction. Minority state owners could exert influence over the target firm beyond their equity rights (Borisova \& Megginson, 2011; Bortolotti \& Faccio, 2009) and may be able to monitor PBC-seeking acquirers' behaviors.

Finally, we included controls for the acquiring firm. Foreign acquirer is a binary variable that takes the value " 1 " if the acquirer is from a different country than the target and " 0 " if the acquirer is from the same country as the target. The variable was collected from SDC Platinum and accounts for foreign acquirers' different legal and cultural origins. 70\% of transactions in our sample are domestic (i.e., the target firm and the acquirer are from the same country) while $30 \%$ are cross-border (i.e., the target firm and the acquirer are from different countries) (see Table 1).

\section{Analysis}

Our sample covers "transactions" of control blocks from one owner (target) to another (acquirer). We have one observation per target, resembling a cross-sectional data structure. These transactions are embedded in higher-level observational units (i.e., countries), meaning the transaction observations are no longer independent and identically distributed (IID) in the same country. These within-country dependencies violate the simple ordinary least squares (OLS) assumption of stochastic independence of the error terms associated with individual observations (Raudenbush \& Bryk, 2002). We therefore use OLS with cluster-robust standard errors. Dummy variables for the transaction years and the industry of the target firms are included in all models. 


\section{RESULTS}

Table 1 includes the descriptive statistics and correlations of the variables included in our conceptual model. Table 2 presents results for our main models. Model 1 is our baseline model, containing only control variables. Confirming earlier findings by Dyck and Zingales (2004), we found that $\mathrm{PBC}$ are higher when the target firm is located in a country with higher propensity to cheat on taxes. Additionally, past firm performance had a positive effect on PBC, suggesting that financially healthy firms are more attractive for controlling shareholders wanting to consume PBC.

Model 2 includes our results for the first hypothesis. Hypothesis 1, predicting a negative effect of state acquirer on PBC was supported $(p<0.05)$. It appears that states indeed use their controlling ownership positions in public companies to reduce PBC. It is also important to interpret these results in terms of their practical significance (Bettis et al., 2016). PBC levels in state acquired firms are 10 percent lower than PBC levels in non-state-controlled firms.

Model 3 includes the interaction term testing Hypothesis 2, predicting that the negative relationship between state acquirer and $\mathrm{PBC}$ will be more negative in target firms located in countries with strong ex-ante anti-self-dealing laws. This hypothesis was confirmed $(p<0.05)$. Figure 1 (Panel A) graphs the interaction effect at low (- 1 SD) and high (+ $1 \mathrm{SD})$ levels of exante anti-self-dealing laws. The PBC reducing effect of states acquiring a controlling ownership position only appears in the high condition, whereas the effect of state acquirer is not significantly different from private controlling acquirers in the low condition. This result 
supports the argument that states suffer a "liability of stateness" when legal institutions are weakly developed.

Model 4 includes the interaction term testing Hypothesis 3, predicting that state acquirer will have a more positive relationship with $\mathrm{PBC}$ when political constraints are higher. This hypothesis was confirmed $(p<0.05)$. Figure 1 (Panel B) graphs the interaction at low $(-1 \mathrm{SD})$ and high (+ $1 \mathrm{SD})$ levels of political constraints, showing a more positive slope when political constraints are higher. State acquirers therefore seem to reduce $\mathrm{PBC}$ only when the state acquirer is relatively unconstrained by competing political factions and complicated political processes.

Model 5 includes the interaction term testing Hypothesis 4, predicting that state acquirer will have a more positive relationship with PBC when state capacity is higher. This hypothesis was also confirmed $(p<0.05)$. Figure 1 (Panel C) graphs the interaction effect at low $(-1 \mathrm{SD})$ and high (+ $1 \mathrm{SD})$ levels of state capacity, supporting the argument that high capacity states are able to use corporations to extract PBC.

[Insert Figure 1 and Tables 1 and 2 about here]

\section{Robustness checks}

We conducted three robustness checks. First, we were concerned about potential selection-based endogeneity issues (Clougherty, Duso, \& Muck, 2016). This selection issue may be present when the acquisition of a controlling ownership stake by a state entity is not random, but driven by strategic considerations such as bailing out ailing firms or supporting industries of national interest (Lazzarini, 2015). We addressed these selection issues by creating a sample of 
transactions that is comparable between transactions in which the state acquires a controlling stake and transactions in which a private entity acquires a controlling stake (Inoue et al., 2013). We used coarsened exact matching (CEM) to reduce the imbalance between treated (i.e., state acquisitions) and control (i.e., private acquisitions) observations (Li, Xia, \& Lin, 2017). CEM reduces imbalance more effectively than other matching techniques (Iacus, King, \& Porro, 2012). We chose to match on prior firm performance, firm size, R\&D expenditures, and financial leverage as these variables have been theorized to be important determinants of PBC (D'Souza \& Nash, 2017). As reported in Table 3, the results are similar to our main findings, even with a reduced sample size. While the fact that our results hold with a matched sample is encouraging, this identification strategy assumes that only observable variables affect the selection bias.

[Insert Table 3 about here]

Second, since our data also include cross-border acquisitions, we need to examine whether our results hold for domestic and cross-border transactions. We commenced by interacting the variable state acquirer with the binary variable foreign acquirer to examine whether the level of PBC extracted varies for domestic versus foreign governments. We expect that foreign governments reduce $\mathrm{PBC}$ to a lesser extent than domestic governments. We find supportive evidence in unreported analyses that show a positive moderating effect between state acquirer and foreign acquirer $(p<0.05)$. A visual inspection of the interaction effect reveals that both slopes are negative, but domestic state acquirers have a more negative effect on PBC. Further, we split our sample along the lines of domestic and foreign acquisitions to examine the 
interaction effects theorized in this paper (Hypotheses 2-4). We see in Table 4 that all theorized effects with a domestic state acquirer continue to be significant and in the expected direction. However, we find that this picture changes for cross-border deals. Foreign states do not significantly reduce PBC in another country. Political institutions (measured in the home country of the target) also create no significant interaction effects, which is expected since political institutions influence predominantly the behavior of domestic political actors. Interestingly, we find that the legal protection of shareholder rights, measured through ex-ante anti-self-dealing laws in the home country of the target, results in a significant interaction term, suggesting that the legal protection of shareholder rights is an effective constraint even on foreign governments.

\section{[Insert Table 4 about here]}

Third, the state capacity measure we used to test Hypothesis 4 is agnostic concerning the content of government policy. Higher state capacity might therefore lead to a weaker main effect when states use their power to divert firm resources to social goals, or to a stronger main effect when states use their influence to implement more sophisticated governance mechanisms to reduce PP problems. To better identify the mechanism at play, we accounted for the content of government policy. Specifically, we ran a three-way interaction with the political ideology of the executive branch (provided by the World Bank Database of Political Institutions (Beck et al., 2001)). Our expectation is that ideologically "left" (socialist or social democratic) governments are more likely to use high state capacity to extract $\mathrm{PBC}$ from the firms they acquire than ideologically "right" (economically liberal and capitalism-supportive) governments. We find 
support for this effect in unreported analyses, which show that the results for Hypothesis 4 are driven by powerful, ideologically "left" governments.

\section{DISCUSSION}

While state ownership of firms is commonly believed to be hurtful to the position of minority shareholders, the phenomenon of state ownership has changed course considerably in recent years (Grosman et al., 2016). Many contemporary SOEs are best conceptualized as partnerships between states and private actors in mixed-ownership enterprises (Benito, Rygh, \& Lunnan, 2016; Bruton et al., 2015; Liu et al., 2015; Musacchio \& Lazzarini, 2014). In such partnerships, states are now more likely than in the past to prioritize the financial performance of these firms, and to refrain from using them as policy implementation vehicles. Under these circumstances, states will avoid extracting PBCs for personal, social, and political goals, and even actively prevent other firm insiders from extracting PBC. In many jurisdictions around the globe, states have begun to scale up their involvement in corporate governance (Musacchio \& Lazzarini, 2014; van Essen et al., 2013). They participate increasingly in the administration and governance of firms by exercising the control rights associated with their ownership positions (CuervoCazurra et al., 2014).

In this study, we have shown that state involvement in firms can help curtail PBC. States may reduce $\mathrm{PBC}$ directly via acquired control ownership positions by appointing inside monitors (Lin \& Germain, 2003), by infusing SOEs with modern management practices (Aivazian et al., 2005), and by bringing the special powers vested in the state to bear on self-benefiting 
transactions (Borisova \& Megginson, 2011). The ability of the state to reduce PBC is enhanced, as we have shown, by the development and implementation of strong ex-ante anti-self-dealing laws. Such laws make it mandatory to get ex-ante approval for related-party transactions (Conac et al., 2007) and to disclose such transactions on an ongoing or periodic basis (Djankov et al., 2008). We have also shown that various facets of political institutions can affect the ability of states to address PBC. Political constraints, which lead to political fragmentation, can make it more difficult for states to realize their policy goal of constraining PBC. State capacity, while in principle necessary for advancing and implementing the state's policy goals, can also act counterproductively when states prioritize social development and the attainment of related policy goals at the country level over and above the realization of financial performance and the upholding of shareholder goals at the firm level.

In short, while prior research frequently overlooks states' ambitions and attempts in the area of curtailing PBC in SOEs (but see exceptions such as Carvalhal da Silva \& Subrahmanyam, 2007; Haß, Johan, \& Müller, 2016), we have shown that states deliberately exert effort and are frequently effective in terms of limiting PBC.

\section{Theoretical implications}

Prior research has primarily stressed the faults and weaknesses associated with state ownership of firms. For example, Dewenter and Malatesta (2001) have shown that in a broad international sample, SOEs are less profitable than non-SOEs because they appear to be trading off cash flows towards minority shareholders against the public policy goal of full employment. Furthermore, 
Wang, Wong, and Xia (2008) show that local SOEs in China tend to avoid reputable accounting firms, opting instead for smaller and more acquiescent local auditors that may facilitate government owners' pursuit of private gains and political goals. When we coalesce these findings, it appears that the dominant view in the SOE literature currently is that minority shareholders face substantial PP agency problems when states are the controlling shareholder and will likely have to bear the costs of soft budgeting, self-dealing, and the pursuit of political goals. Our study puts forward important theoretical implications that nuance this dominant view.

First, to the SOE literature (Cuervo-Cazurra et al., 2014; Musacchio et al., 2015), we add a stewardship perspective on the role of the state in corporate governance, which complements the often invoked agency theoretical perspective of SOEs (Musacchio et al., 2015). We show that minority shareholders frequently also benefit from being associated with a firm in which the state becomes a controlling owner. Our study supports the view that in the past two decades, states have accepted a more active and strategic role in corporate governance (Bruton et al., 2015; Musacchio \& Lazzarini, 2014). We interpret these findings as evidence for a stewardship perspective on state capitalism (Aguilera \& Jackson, 2003), suggesting that states and politicians are ready to combat $\mathrm{PBC}$, which eventually benefit minority shareholders. Thus, rather than treating government involvement in corporate governance as an agency problem in its own right, we encourage researchers to also apply the alternate stewardship frame. In a stewardly take on government participation in corporate governance, states are seen as influential actors committed to making interventions in the economy that will lead to positive change. These actions may aim 
at protecting the interests of minority shareholders, refraining from coopting SOEs for the pursuit of policy objectives that do not benefit the immediately involved stakeholders, or breaking the power of entrenched insiders.

Second, we advance the international business literature (Hoskisson et al., 2013; Peng et al., 2009) by calling greater attention to the cross-level conditioning effects of legal and political institutions on firm behavior. To understand the behavior of state owners, it is essential to consider the institutional context in which they operate, because even state owners (not only private owners) are simultaneously constrained and empowered by institutions (cf. Peng \& Luo, 2000). Our study provides a case in point. Unlike many institution-based view authors before us, we do not theoretically focus on the direct effects institutions have on micro-outcomes. Instead, we hypothesize and demonstrate that the effects of institutions operate by empowering or inhibiting state acquirers at the micro-level. Stronger legal and political institutions thus can help make state-acquired corporations more accountable towards minority shareholders (Lazzarini, 2015; Musacchio \& Lazzarini, 2014; Musacchio et al., 2015). Clearly, this is only one example of how the institutional context produces firm- and societal-level outcomes by imposing constraints on micro-level actors (Peng et al., 2009). Theoretically, however, this example calls upon institution-based view scholars to pay greater attention to the mechanisms engendering concrete interactions between legal and political institutions and organization-level actors (Martin, 2014). 


\section{Future research}

Our study opens the door to several fruitful research opportunities. First, there is ample evidence to support both the agency view (Dharwadkar et al., 2000) and stewardship perspectives (Inoue et al., 2013) on state involvement in private corporations. While our study has made first attempts into uncovering the costs and benefits of state influence in $\mathrm{PBC}$ reduction, future research must establish a clearer balance of the evidence. An important avenue is to identify the firm-level conditions determining whether state acquirers will act as opportunistic agents or helpful stewards. Second, prior institution-based studies have not so much ignored the role of micro-level agency, but they have left it largely implicit or, when explicitly theorized, empirically untested (Ingram \& Silverman, 2002; Peng et al., 2009; Wan \& Hoskisson, 2003). We encourage institutional scholars to more explicitly theorize the underlying microfoundations.

\section{CONCLUSION}

Scholars are increasingly recognizing that states are able to play a more active and strategic role in corporate governance (Musacchio et al., 2015; Stephan et al., 2015). However, many important questions concerning this more active role remain unaddressed. In this paper, we touched upon one of these questions: How do state owners affect private benefits of control? Our study, in which we measured and analyzed PBC via acquisitions of controlling ownership positions in 54 countries across the globe, yielded important evidence to help answer this question. Effective states do not shun involvement in corporate governance. Our results thus paint a picture of modern states as stewards, capable of keeping their own representatives in 
check and working together with firms and minority shareholders in the spirit of mutually beneficial public-private partnerships. We also find evidence that the extent to which state owners reduce $\mathrm{PBC}$ depends on the legal and political institutions that can either inhibit or empower state owners to reduce PBC.

\section{ACKNOWLEDGEMENTS}

We are grateful for the guidance of our editor, Gabriel Benito, and the two anonymous reviewers. We also appreciate helpful comments from seminar participants at the 2016 Academy of Management Meeting and the 2016 International Corporate Governance Society Conference.

\section{REFERENCES}

Acemoglu, D., Moscona, J., \& Robinson, J. A. (2016). State capacity and American technology: Evidence from the nineteenth century. American Economic Review, 106, 61-67. https://doi.org/10.1257/aer.p20161071

Acemoglu, D., \& Robinson, J. (2012). Why nations fail: The origins of power, prosperity, and poverty. New York: Crown Business.

Aguilera, R. V., \& Jackson, G. (2003). The cross-national diversity of corporate governance: Dimensions and determinants. Academy of Management Review, 28, 447-465. https://doi.org/10.2307/30040732

Aivazian, V. A., Ge, Y., \& Qiu, J. (2005). The impact of leverage on firm investment: Canadian evidence. Journal of Corporate Finance, 11, 277-291. https://doi.org/10.1016/S09291199(03)00062-2

Albuquerque, R., \& Schroth, E. (2010). Quantifying private benefits of control from a structural model of block trades. Journal of Financial Economics, 96, 33-55. https://doi.org/10.1016/j.jfineco.2009.12.003

Albuquerque, R., \& Schroth, E. (2015). The value of control and the costs of illiquidity. Journal of Finance, 70, 1405-1455. https://doi.org/10.1111/jofi.12207

Bai, C.-E., \& Xu, L. C. (2005). Incentives for CEOs with multitasks: Evidence from Chinese stateowned enterprises. Journal of Comparative Economics, 33, 517-539. https://doi.org/10.1016/j.jce.2005.03.013

Barclay, M. J., \& Holderness, C. G. (1989). Private benefits from control of public corporations. Journal of Financial Economics, 25, 371-395. https://doi.org/10.1016/0304-405X(89)90088-3 
Bebchuk, L. A. (2005). The case for increasing shareholder power. Harvard Law Review, 118, 833914. https://doi.org/10.2139/ssrn.631344

Beck, T., Clarke, G., Groff, A., Keefer, P., \& Walsh, P. (2001). New tools in comparative political economy: The database of political institutions. World Bank Economic Review, 15, 165-176. https://doi.org/10.1093/wber/15.1.165

Beck, T., Demirgüç-Kunt, A., \& Levine, R. (2007). Finance, inequality and the poor. Journal of Economic Growth, 12, 27-49. https://doi.org/10.1007/s10887-007-9010-6

Benito, G. R. G., Rygh, A., \& Lunnan, R. (2016). The benefits of internationalization for state-owned enterprises. Global Strategy Journal, 6, 269-288. https://doi.org/10.1002/gsj.1138

Bennedsen, M., \& Nielsen, K. M. (2010). Incentive and entrenchment effects in European ownership. Journal of Banking \& Finance, 34, 2212-2229. https://doi.org/10.1016/j.jbankfin.2010.02.007

Bettis, R. A., Ethiraj, S., Gambardella, A., Helfat, C., \& Mitchell, W. (2016). Creating repeatable cumulative knowledge in strategic management. Strategic Management Journal, 37, 257-261. https://doi.org/10.1002/smj.2477

Borisova, G., \& Megginson, W. L. (2011). Does government ownership affect the cost of debt? Evidence from privatization. Review of Financial Studies, 24, 2693-2737. https://doi.org/10.1093/rfs/hhq154

Bortolotti, B., Cambini, C., \& Rondi, L. (2013). Reluctant regulation. Journal of Comparative Economics, 41, 804-828. https://doi.org/10.1016/j.jce.2012.12.003

Bortolotti, B., \& Faccio, M. (2009). Government control of privatized firms. Review of Financial Studies, 22, 2907-2939. https://doi.org/10.1093/rfs/hhn077

Bortolotti, B., \& Pinotti, P. (2008). Delayed privatization. Public Choice, 136, 331-351. https://doi.org/10.1007/s11127-008-9299-5

Boubakri, N., Cosset, J.-C., Guedhami, O., \& Saffar, W. (2011). The political economy of residual state ownership in privatized firms: Evidence from emerging markets. Journal of Corporate Finance, 17, 244-258. https://doi.org/10.1016/j.jcorpfin.2010.08.003

Bruton, G. D., Peng, M. W., Ahlstrom, D., Stan, C., \& Xu, K. (2015). State-owned enterprises around the world as hybrid organizations. Academy of Management Perspectives, 29, 92-114. https://doi.org/10.5465/amp.2013.0069

Burbidge, J. B., Magee, L., \& Robb, A. L. (1988). Alternative transformations to handle extreme values of the dependent variable. Journal of the American Statistical Association, 83, 123-127. https://doi.org/10.2307/2288929

Carvalhal da Silva, A., \& Subrahmanyam, A. (2007). Dual-class premium, corporate governance, and the mandatory bid rule: Evidence from the Brazilian stock market. Journal of Corporate Finance, 13, 1-24. https://doi.org/10.1016/j.jcorpfin.2006.12.003

Céspedes, J., González, M., \& Molina, C. A. (2010). Ownership and capital structure in Latin America. Journal of Business Research, 63, 248-254. https://doi.org/10.1016/j.jbusres.2009.03.010

Claessens, S., Djankov, S., Fan, J. P. H., \& Lang, L. H. P. (2002). Disentangling the incentive and entrenchment effects of large shareholdings. Journal of Finance, 57, 2741-2771. https://doi.org/10.1111/1540-6261.00511 
Claessens, S., Feijen, E., \& Laeven, L. (2008). Political connections and preferential access to finance: The role of campaign contributions. Journal of Financial Economics, 88, 554-580. https://doi.org/10.1016/j.jfineco.2006.11.003

Clougherty, J. A., Duso, T., \& Muck, J. (2016). Correcting for self-selection based endogeneity in management research: Review, recommendations and simulations. Organizational Research Methods, 19, 286-347. https://doi.org/10.1177/1094428115619013

Conac, P.-H., Enriques, L., \& Gelter, M. (2007). Constraining dominant shareholders' self-dealing: The legal framework in France, Germany, and Italy. European Company and Financial Law Review, 4, 491-528. https://doi.org/10.1515/ecfr.2007.025

Cuervo-Cazurra, A., Inkpen, A., Musacchio, A., \& Ramaswamy, K. (2014). Governments as owners: State-owned multinational companies. Journal of International Business Studies, 45, 919-942. https://doi.org/10.1057/jibs.2014.43

Cull, R., \& Xu, L. C. (2005). Institutions, ownership, and finance: The determinants of profit reinvestment among Chinese firms. Journal of Financial Economics, 77, 117-146. https://doi.org/10.1016/j.jfineco.2004.05.010

Dalton, D. R., Daily, C. M., Certo, S. T., \& Roengpitya, R. (2003). Meta-analyses of financial performance and equity: Fusion or confusion? Academy of Management Journal, 46, 13-26. https://doi.org/10.5465/30040673

Dewenter, K. L., \& Malatesta, P. H. (2001). State-owned and privately owned firms: An empirical analysis of profitability, leverage, and labor intensity. American Economic Review, 91, 320-334. https://doi.org/10.1257/aer.91.1.320

Dharwadkar, R., George, G., \& Brandes, P. (2000). Privatization in emerging economies: An agency theory perspective. Academy of Management Review, 25, 650-669. https://doi.org/10.2307/259316

Dinc, I. S., \& Gupta, N. (2011). The decision to privatize: Finance and politics. Journal of Finance, 66, 241-269. https://doi.org/10.1111/j.1540-6261.2010.01631.x

Djankov, S., La Porta, R., Lopez-de-Silanes, F., \& Shleifer, A. (2008). The law and economics of self-dealing. Journal of Financial Economics, 88, 430-465. https://doi.org/10.1016/j.jfineco.2007.02.007

D'Souza, J., \& Nash, R. (2017). Private benefits of public control: Evidence of political and economic benefits of state ownership. Journal of Corporate Finance, 46, 232-247. https://doi.org/10.1016/j.jcorpfin.2017.07.001

Duanmu, J.-L. (2014). State-owned MNCs and host country expropriation risk: The role of home state soft power and economic gunboat diplomacy. Journal of International Business Studies, 45, 1044-1060. https://doi.org/10.1057/jibs.2014.16

Dyck, A., Volchkova, N., \& Zingales, L. (2008). The corporate governance role of the media: Evidence from Russia. Journal of Finance, 63, 1093-1135. https://doi.org/10.1111/j.15406261.2008.01353.x

Dyck, A., \& Zingales, L. (2004). Private benefits of control: An international comparison. Journal of Finance, 59, 537-600. https://doi.org/10.1111/j.1540-6261.2004.00642.x

Edmans, A., \& Manso, G. (2011). Governance through trading and intervention: A theory of multiple blockholders. Review of Financial Studies, 24, 2395-2428. https://doi.org/10.1093/rfs/hhq145 
Enriques, L. (2000). The law on company directors' self-dealing: A comparative analysis. International and Comparative Corporate Law Journal, 2, 297-333. https://doi.org/10.2139/ssrn.135674

Faccio, M., \& Lang, L. H. P. (2002). The ultimate ownership of Western European corporations. Journal of Financial Economics, 65, 365-395. https://doi.org/10.1016/S0304-405X(02)00146-0

Fan, J. P. H., Wong, T. J., \& Zhang, T. (2007). Politically connected CEOs, corporate governance, and post-IPO performance of China's newly partially privatized firms. Journal of Financial Economics, 84, 330-357. https://doi.org/10.1016/j.jfineco.2006.03.008

Fidrmuc, J. P., Korczak, A., \& Korczak, P. (2013). Why does shareholder protection matter for abnormal returns after reported insider purchases and sales? Journal of Banking \& Finance, 37, 1915-1935. https://doi.org/10.1016/j.jbankfin.2012.06.019

Filatotchev, I., Buck, T., \& Zhukov, V. (2000). Downsizing in privatized firms in Russia, Ukraine, and Belarus. Academy of Management Journal, 43, 286-304. https://doi.org/10.2307/1556396

Filatotchev, I., Kapelyushnikov, R., Dyomina, N., \& Aukutsionek, S. (2001). The effects of ownership concentration on investment and performance in privatized firms in Russia. Managerial and Decision Economics, 22, 299-313. https://doi.org/10.1002/mde.1008.abs

Fourcade, M. (2009). Economists and societies: Discipline and profession in the United States, Britain, and France, 1890s to 1990s. Princeton, NJ: Princeton University Press.

Franks, J., Mayer, C., \& Rossi, S. (2009). Ownership: Evolution and regulation. Review of Financial Studies, 22, 4009-4056. https://doi.org/10.1093/rfs/hhn108

Fukuyama, F. (2013). What is governance? Governance, 26, 347-368. https://doi.org/10.1111/gove.12035

Garcia-Canal, E., \& Guillén, M. F. (2008). Risk and the strategy of foreign location choice in regulated industries. Strategic Management Journal, 29, 1097-1115. https://doi.org/10.1002/smj.692

Gilson, R. J. (2006). Controlling shareholders and corporate governance: Complicating the comparative taxonomy. Harvard Law Review, 119, 1641-1679. https://doi.org/10.2139/ssrn.784744

Gilson, R. J., \& Schwartz, A. (2013). Constraints on private benefits of control: Ex ante control mechanisms versus ex post transaction review. Journal of Institutional and Theoretical Economics, 169, 160-183. https://doi.org/10.1628/093245613X660537

Golden, B. R., \& Zajac, E. J. (2001). When will boards influence strategy? Inclination x power = strategic change. Strategic Management Journal, 22, 1087-1111. https://doi.org/10.1002/smj.202

Gomez-Mejia, L. R., Larraza-Kintana, M., \& Makri, M. (2003). The determinants of executive compensation in family-controlled public corporations. Academy of Management Journal, 46, 226-237. https://doi.org/10.2307/30040616

Grosman, A., Okhmatovskiy, I., \& Wright, M. (2016). State control and corporate governance in transition economies: 25 years on from 1989. Corporate Governance: An International Review, 24, 200-221. https://doi.org/10.1111/corg.12145

Guillén, M. F., \& Capron, L. (2016). State capacity, minority shareholder protections, and stock market development. Administrative Science Quarterly, 61, 125-160. https://doi.org/10.1177/0001839215601459 
Gupta, M., Prakash, P., \& Rangan, N. K. (2013). Equity issue-specific versus broad regulatory protections against expropriation risk: International evidence from SEOs. Journal of International Money and Finance, 35, 146-166. https://doi.org/10.1016/j.jimonfin.2013.02.003

Gupta, N. (2005). Partial privatization and firm performance. Journal of Finance, 60, 987-1015. https://doi.org/10.1111/j.1540-6261.2005.00753.x

Haidar, J. I. (2009). Investor protections and economic growth. Economics Letters, 103, 1-4. https://doi.org/10.1016/j.econlet.2008.12.007

Hambrick, D. C., \& Fukutomi, G. D. S. (1991). The seasons of a CEO's tenure. Academy of Management Review, 16, 719-742. https://doi.org/10.2307/258978

Hanson, J. K. (2014). Forging then taming Leviathan: State capacity, constraints on rulers, and development. International Studies Quarterly, 58, 380-392. https://doi.org/10.1111/isqu.12122

Hanson, J. K., \& Sigman, R. (2013). Leviathan's latent dimensions: Measuring state capacity for comparative political research (Working paper). Ann Arbor, MI: University of Michigan. Retrieved from http://papers.ssrn.com/abstract=1899933

Haß, L. H., Johan, S., \& Müller, M. A. (2016). The effectiveness of public enforcement: Evidence from the resolution of tunneling in China. Journal of Business Ethics, 134, 649-668. https://doi.org/10.1007/s10551-014-2389-z

Hayward, M. L. A., \& Hambrick, D. C. (1997). Explaining the premiums paid for large acquisitions: Evidence of CEO hubris. Administrative Science Quarterly, 42, 103-127. https://doi.org/10.2307/2393810

Hendry, J. (2002). The principal's other problems: Honest incompetence and the specification of objectives. Academy of Management Review, 27, 98-113. https://doi.org/10.5465/AMR.2002.5922406

Henisz, W. J. (2000). The institutional environment for economic growth. Economics \& Politics, 12, 1-31. https://doi.org/10.1111/1468-0343.00066

Holburn, G. L. F., \& Zelner, B. A. (2010). Political capabilities, policy risk, and international investment strategy: Evidence from the global electric power generation industry. Strategic Management Journal, 31, 1290-1315. https://doi.org/10.1002/smj.860

Holderness, C. G. (2009). The myth of diffuse ownership in the United States. Review of Financial Studies, 22, 1377-1408. https://doi.org/10.1093/rfs/hhm069

Hoskisson, R. E., Wright, M., Filatotchev, I., \& Peng, M. W. (2013). Emerging multinationals from mid-range economies: The influence of institutions and factor markets. Journal of Management Studies, 50, 1295-1321. https://doi.org/10.1111/j.1467-6486.2012.01085.x

Hou, W., \& Moore, G. (2011). Player and referee roles held jointly: The effect of state ownership on China's regulatory enforcement against fraud. Journal of Business Ethics, 95, 317-335. https://doi.org/10.1007/s10551-011-0858-1

Iacus, S. M., King, G., \& Porro, G. (2012). Causal inference without balance checking: Coarsened exact matching. Political Analysis, 20, 1-24. https://doi.org/10.1093/pan/mpr013

Ingram, P., \& Silverman, B. S. (2002). Introduction. In P. Ingram \& B. S. Silverman (Eds.), The New Institutionalism in Strategic Management (Vol. 19, pp. 1-30). Greenwich, CT: JAI Press. 
Inoue, C. F. K. V., Lazzarini, S. G., \& Musacchio, A. (2013). Leviathan as a minority shareholder: Firm-level implications of state equity purchases. Academy of Management Journal, 56, 17751801. https://doi.org/10.5465/amj.2012.0406

Jackson, G. (2010). Actors and institutions. In G. Morgan, J. Campbell, C. Crouch, O. K. Pedersen, \& R. Whitley (Eds.), The Oxford Handbook of Comparative Institutional Analysis (pp. 63-86). New York: Oxford University Press. Retrieved from http://ssrn.com/paper=1408664

Jensen, M. C. (2002). Value maximization, stakeholder theory, and the corporate objective function. Business Ethics Quarterly, 12, 235-256. https://doi.org/10.2307/3857812

Jensen, M. C., \& Meckling, W. H. (1976). Theory of the firm: Managerial behavior, agency costs and ownership structure. Journal of Financial Economics, 3, 305-360. https://doi.org/10.1016/0304405x(76)90026-x

Johnson, N. L. (1949). Systems of frequency curves generated by methods of translation. Biometrika, 36, 149-176. https://doi.org/10.1093/biomet/36.1-2.149

Johnson, S., La Porta, R., Lopez-de-Silanes, F., \& Shleifer, A. (2000). Tunneling. American Economic Review, 90, 22-27. https://doi.org/10.1257/aer.90.2.22

Kaufmann, D., Kraay, A., \& Mastruzzi, M. (2009). Governance matters VIII: Aggregate and individual governance indicators 1996-2008 (Working paper). Washington, D.C.: World Bank.

Krause, R., Whitler, K., \& Semadeni, M. (2014). Power to the principals! An experimental look at shareholder say-on-pay voting. Academy of Management Journal, 57, 94-115. https://doi.org/10.5465/amj.2012.0035

La Porta, R., Lopez-de-Silanes, F., \& Shleifer, A. (1999). Corporate ownership around the world. Journal of Finance, 54, 471-517. https://doi.org/10.1111/0022-1082.00115

La Porta, R., Lopez-de-Silanes, F., Shleifer, A., \& Vishny, R. W. (1998). Law and finance. Journal of Political Economy, 106, 1113-1155. https://doi.org/10.3386/w5661

Lazzarini, S. G. (2015). Strategizing by the government: Can industrial policy create firm -level competitive advantage? Strategic Management Journal, 36, 97-112. https://doi.org/10.1002/smj.2204

Li, J., \& Qian, C. (2013). Principal-principal conflicts under weak institutions: A study of corporate takeovers in China. Strategic Management Journal, 34, 498-508. https://doi.org/10.1002/smj.2027

Li, J., Xia, J., \& Lin, Z. (2017). Cross-border acquisitions by state-owned firms: How do legitimacy concerns affect the completion and duration of their acquisitions? Strategic Management Journal, 38, 1915-1934. https://doi.org/10.1002/smj.2609

Licht, A. N., Goldschmidt, C., \& Schwartz, S. H. (2007). Culture rules: The foundations of the rule of law and other norms of governance. Journal of Comparative Economics, 35, 659-688. https://doi.org/10.1016/j.jce.2007.09.001

Lin, C.-Y., Tsai, W.-C., Hasan, I., \& Tuan, L. Q. (2018). Private benefits of control and bank loan contracts. Journal of Corporate Finance, 49, 324-343. https://doi.org/10.1016/j.jcorpfin.2018.01.006

Lin, X., \& Germain, R. (2003). Organizational structure, context, customer orientation, and performance: Lessons from Chinese state-owned enterprises. Strategic Management Journal, 24, 1131-1151. https://doi.org/10.1002/smj.348 
Liu, G. S., Beirne, J., \& Sun, P. (2015). The performance impact of firm ownership transformation in China: Mixed ownership vs. fully privatised ownership. Journal of Chinese Economic and Business Studies, 13, 197-216. https://doi.org/10.1080/14765284.2015.1056476

Liu, M., \& Magnan, M. (2011). Self-dealing regulations, ownership wedge, and corporate valuation: International evidence. Corporate Governance: An International Review, 19, 99-115. https://doi.org/10.1111/j.1467-8683.2010.00839.x

Liu, Q., \& Siu, A. (2012). Institutions and corporate investment: Evidence from investment-implied return on capital in China. Journal of Financial and Quantitative Analysis, 46, 1831-1863. https://doi.org/10.1017/S0022109011000494

March, J. G., \& Olsen, J. P. (1989). Rediscovering institutions: The organizational basis of politics. New York: Free Press.

Martin, X. (2014). Institutional advantage. Global Strategy Journal, 4, 55-69. https://doi.org/10.1111/j.2042-5805.2013.01072.x

Megginson, W. L., \& Netter, J. M. (2001). From state to market: A survey of empirical studies on privatization. Journal of Economic Literature, 39, 321-389. https://doi.org/10.2307/2698243

Morck, R., Shleifer, A., \& Vishny, R. W. (1988). Management ownership and market valuation: An empirical analysis. Journal of Financial Economics, 20, 293-315. https://doi.org/10.1016/0304405X(88)90048-7

Morck, R., Wolfenzon, D., \& Yeung, B. (2005). Corporate governance, economic entrenchment, and growth. Journal of Economic Literature, 43, 655-720. https://doi.org/10.1257/002205105774431252

Musacchio, A., \& Lazzarini, S. G. (2014). Reinventing state capitalism: Leviathan in business, Brazil and beyond. Cambridge: Harvard University Press.

Musacchio, A., Lazzarini, S. G., \& Aguilera, R. V. (2015). New varieties of state capitalism: Strategic and governance implications. Academy of Management Perspectives, 29, 115-131. https://doi.org/10.5465/amp.2013.0094

Nenova, T. (2003). The value of corporate voting rights and control: A cross-country analysis. Journal of Financial Economics, 68, 325-351. https://doi.org/10.1016/S0304-405X(03)00069-2

Nicodano, G., \& Sembenelli, A. (2004). Private benefits, block transaction premiums and ownership structure. International Review of Financial Analysis, 13, 227-244. https://doi.org/10.1016/j.irfa.2004.02.006

Nyberg, A. J., Fulmer, I. S., Gerhart, B., \& Carpenter, M. A. (2010). Agency theory revisited: CEO return and shareholder interest alignment. Academy of Management Journal, 53, 1029-1049. https://doi.org/10.5465/amj.2010.54533188

Park, S. H., Li, S., \& Tse, D. K. (2006). Market liberalization and firm performance during China's economic transition. Journal of International Business Studies, 37, 127-147. https://doi.org/10.1057/palgrave.jibs.8400178

Peng, M. W. (2003). Institutional transitions and strategic choices. Academy of Management Review, 28, 275-296. https://doi.org/10.2307/30040713

Peng, M. W. (2004). Outside directors and firm performance during institutional transitions. Strategic Management Journal, 25, 453-471. https://doi.org/10.1002/smj.390 
Peng, M. W., Bruton, G. D., Stan, C. V., \& Huang, Y. (2016). Theories of the (state-owned) firm. Asia Pacific Journal of Management, 33, 293-317. https://doi.org/10.1007/s10490-016-9462-3

Peng, M. W., \& Luo, Y. (2000). Managerial ties and firm performance in a transition economy: The nature of a micro-macro link. Academy of Management Journal, 43, 486-501. https://doi.org/10.5465/1556406

Peng, M. W., \& Sauerwald, S. (2013). Principal-principal conflicts. In M. Wright, D. S. Siegel, K. Keasey, \& I. Filatotchev (Eds.), The Oxford Handbook of Corporate Governance (pp. 658-672). New York: Oxford University Press.

Peng, M. W., Sun, S. L., Pinkham, B., \& Chen, H. (2009). The institution-based view as a third leg for a strategy tripod. Academy of Management Perspectives, 23, 63-81. https://doi.org/10.5465/amp.2009.43479264

Raudenbush, S. W., \& Bryk, A. S. (2002). Hierarchical linear models: Applications and data analysis methods (2nd ed.). Thousand Oaks, CA: Sage.

Reuters. (2015, March 17). America Movil to increase funds for share buybacks in 2015. Reuters. Retrieved from https://goo.gl/AqGDL8

Rudy, B. C., Miller, S. R., \& Wang, D. (2016). Revisiting FDI strategies and the flow of firmspecific advantages: A focus on state-owned enterprises. Global Strategy Journal, 6, 69-78. https://doi.org/10.1002/gsj.1106

Sauerwald, S., Lin, Z., \& Peng, M. W. (2016). Board social capital and excess CEO returns. Strategic Management Journal, 37, 498-520. https://doi.org/10.1002/smj.2339

Sauerwald, S., \& Peng, M. W. (2013). Informal institutions, shareholder coalitions, and principalprincipal conflicts. Asia Pacific Journal of Management, 30, 853-870. https://doi.org/10.1007/s10490-012-9312-x

Shi, W., Hoskisson, R. E., \& Zhang, Y. A. (2016). A geopolitical perspective into the opposition to globalizing state-owned enterprises in target states. Global Strategy Journal, 6, 13-30. https://doi.org/10.1002/gsj.1105

Shleifer, A. (2010). Efficient regulation. In D. P. Kessler (Ed.), Regulation Versus Litigation: Perspectives from Economics and Law (pp. 27-43). Chicago: University of Chicago Press.

Shleifer, A., \& Vishny, R. W. (1986). Large shareholders and corporate control. Journal of Political Economy, 94, 461-488. https://doi.org/10.1086/261385

Shleifer, A., \& Vishny, R. W. (1994). Politicians and firms. Quarterly Journal of Economics, 109, 995-1025. https://doi.org/10.2307/2118354

Shleifer, A., \& Vishny, R. W. (Eds.). (1998). The grabbing hand: Government pathologies and their cures. Cambridge, MA: Harvard University Press.

Shughart, W. F., \& Razzolini, L. (Eds.). (2003). The Elgar companion to public choice. Cheltenham: Edward Elgar.

Singla, C., Veliyath, R., \& George, R. (2014). Family firms and internationalization-governance relationships: Evidence of secondary agency issues. Strategic Management Journal, 35, 606616. https://doi.org/10.1002/smj.2111

Slangen, A. H. L. (2013). Greenfield or acquisition entry? The roles of policy uncertainty and MNE legitimacy in host countries. Global Strategy Journal, 3, 262-280. https://doi.org/10.1111/j.20425805.2013.01056.x 
Stephan, U., Uhlaner, L. M., \& Stride, C. (2015). Institutions and social entrepreneurship: The role of institutional voids, institutional support, and institutional configurations. Journal of International Business Studies, 46, 308-331. https://doi.org/10.1057/jibs.2014.38

Sun, P., Hu, H. W., \& Hillman, A. J. (2016). The dark side of board political capital: Enabling blockholder rent appropriation. Academy of Management Journal, 59, 1801-1822. https://doi.org/10.5465/amj.2014.0425

Sundaram, A. K., \& Inkpen, A. C. (2004). The corporate objective revisited. Organization Science, 15, 350-363. https://doi.org/10.1287/orsc.1040.0068

The Economist. (2004, March 18). A deal in Brazil: Slim pickings. The Economist. Retrieved from https://goo.gl/M3cDjp

The Economist. (2008, July 10). Telecoms in Mexico: Slim's pickings. The Economist. Retrieved from https://goo.gl/PLBxS8

The Economist. (2012a, January 21). Special report: State capitalism. The Economist, 1-18.

The Economist. (2012b, February 4). Carlos Slim: Let Mexico's moguls battle. The Economist. Retrieved from https://goo.gl/XLwqxZ

The Economist. (2013a, May 1). Plutocrats and their progeny: A secretive fathers-and-sons knees-up for billionaires. The Economist. Retrieved from https://goo.gl/mFE9UW

The Economist. (2013b, September 7). Hunting tigers. The Economist. Retrieved from https://goo.gl/v36rpu

The Economist. (2014a, July 12). Telecoms in Mexico: Slimming down. The Economist. Retrieved from https://goo.gl/TmWney

The Economist. (2014b, November 22). State capitalism in the dock. The Economist. Retrieved from https://goo.gl/Hdc2VW

The Economist. (2014c, December 13). Tiger in the net. The Economist. Retrieved from https://goo.gl/KMtETp

Vaaler, P. M., \& Schrage, B. N. (2009). Residual state ownership, policy stability and financial performance following strategic decisions by privatizing telecoms. Journal of International Business Studies, 40, 621-641. https://doi.org/10.1057/jibs.2008.104

van Essen, M., Heugens, P. P. M. A. R., Otten, J., \& van Oosterhout, J. (2012). An institution-based view of executive compensation: A multilevel meta-analytic test. Journal of International Business Studies, 43, 396-423. https://doi.org/10.1057/jibs.2012.6

van Essen, M., van Oosterhout, J., \& Heugens, P. P. M. A. R. (2013). Competition and cooperation in corporate governance: The effects of labor institutions on blockholder effectiveness in 23 European countries. Organization Science, 24, 530-551. https://doi.org/10.1287/orsc.1120.0742

Villalonga, B., \& Amit, R. (2006). How do family ownership, control and management affect firm value? Journal of Financial Economics, $80, \quad 385-417$. https://doi.org/10.1016/j.jfineco.2004.12.005

Wan, W. P., \& Hoskisson, R. E. (2003). Home country environments, corporate diversification strategies, and firm performance. Academy of Management Journal, 46, 27-45. https://doi.org/10.5465/30040674 
Wang, Q., Wong, T. J., \& Xia, L. (2008). State ownership, the institutional environment, and auditor choice: Evidence from China. Journal of Accounting and Economics, 46, 112-134. https://doi.org/10.1016/j.jacceco.2008.04.001

Weingast, B. R. (1995). The economic role of political institutions: Market-preserving federalism and economic development. Journal of Law, Economics, \& Organization, 11, 1-31. https://doi.org/10.1093/oxfordjournals.jleo.a036861

Witt, M. A., \& Lewin, A. Y. (2007). Outward foreign direct investment as escape response to home country institutional constraints. Journal of International Business Studies, 38, 579-594. https://doi.org/10.1057/palgrave.jibs.8400285

Wood, G., \& Wright, M. (2015). Corporations and new statism: Trends and research priorities. Academy of Management Perspectives, 29, 271-286. https://doi.org/10.5465/amp.2013.0006

Young, M. N., Peng, M. W., Ahlstrom, D., Bruton, G. D., \& Jiang, Y. (2008). Corporate governance in emerging economies: A review of the principal-principal perspective. Journal of Management Studies, 45, 196-220. https://doi.org/10.1111/j.1467-6486.2007.00752.x

Zingales, L. (1994). The value of the voting right: A study of the Milan Stock Exchange experience. Review of Financial Studies, 7, 125-148. https://doi.org/10.1093/rfs/7.1.125

Zou, H., \& Adams, M. B. (2008). Corporate ownership, equity risk and returns in the People's Republic of China. Journal of International Business Studies, 39, 1149-1168. https://doi.org/10.1057/palgrave.jibs.8400394 
T- Jle 1: Descriptive statistics and correlations

\section{\# Variable Name \\ Mean SD}

1 ivate benefits of control (PBC)

2 GDP/capita

C ock market capitalization

+ Cheating on taxes

eedom of press

6 Rule of law

ontrol of corruption

8 Ex-post anti-self-dealing laws

9 Firm size

u $\wedge \& D$ spending

11 Financial leverage

ior financial performance

13 Government sell-out

14 State minority control in target

15 Foreign acquirer

16 Ex-ante anti-self-dealing laws

$\begin{array}{lll}0.44 & 2.48 & 1.00\end{array}$

$23.27 \quad 14.88 \quad-0.01 \quad 1.00$

$\begin{array}{llllll}81.21 & 76.12 & -0.09 & 0.32 & 1.00\end{array}$

$\begin{array}{lllllll}2.16 & 0.49 & 0.18 & -0.05 & -0.09 & 1.00\end{array}$

$\begin{array}{lllllll}28.74 & 27.99 & -0.09 & -0.50 & -0.23 & -0.04 & 1.00\end{array}$

$\begin{array}{llllllll}5.37 & 6.18 & -0.03 & 0.52 & 0.13 & -0.03 & -0.08 & 1.00\end{array}$

$\begin{array}{lllllllll}0.93 & 1.07 & 0.07 & 0.61 & -0.02 & 0.03 & -0.53 & 0.27 & 1.00\end{array}$

$\begin{array}{lllllllllll}0.73 & 0.19 & -0.01 & 0.25 & 0.22 & 0.01 & -0.29 & -0.05 & 0.41 & 1.00\end{array}$

$\begin{array}{lllllllllll}83.71 & 307.79 & 0.04 & 0.07 & 0.06 & 0.03 & -0.07 & 0.06 & 0.05 & 0.00 & 1.00\end{array}$

$\begin{array}{lllllllllllll}3.13 & 0.89 & 0.06 & -0.10 & -0.07 & 0.05 & 0.09 & -0.12 & -0.09 & -0.09 & 0.11 & 1.00\end{array}$

$\begin{array}{llllllllllllll}3.90 & 1.99 & 0.02 & -0.11 & -0.10 & 0.04 & 0.00 & -0.17 & 0.05 & 0.07 & 0.12 & 0.17 & 1.00\end{array}$

$\begin{array}{lllllllllllllll}1.63 & 69.15 & 0.06 & -0.09 & -0.07 & -0.03 & 0.06 & -0.03 & -0.09 & -0.08 & 0.00 & 0.05 & -0.03 & 1.00\end{array}$

$\begin{array}{llllllllllllllll}0.05 & 0.23 & -0.06 & -0.19 & -0.11 & -0.09 & 0.20 & -0.09 & -0.15 & -0.14 & 0.00 & 0.06 & 0.06 & 0.00 & 1.00\end{array}$

$\begin{array}{lllllllllllllllll}0.05 & 0.22 & 0.06 & 0.04 & 0.13 & 0.04 & -0.04 & 0.03 & -0.07 & 0.04 & 0.10 & -0.02 & -0.02 & -0.02 & 0.04 & 1.00\end{array}$

$\begin{array}{llllllllllllllllll}0.30 & 0.46 & 0.08 & 0.08 & -0.10 & 0.05 & -0.07 & 0.07 & 0.17 & -0.04 & 0.06 & -0.05 & 0.00 & 0.02 & -0.03 & 0.04 & 1.00\end{array}$

$\begin{array}{lllllllllllllllllllll}0.62 & 0.31 & -0.08 & -0.35 & -0.10 & -0.01 & 0.41 & -0.14 & -0.20 & 0.01 & -0.14 & 0.02 & -0.08 & 0.03 & 0.08 & -0.04 & -0.05 & 1.00\end{array}$

$\begin{array}{lllllllllllllllllll}0.58 & 0.34 & 0.11 & 0.43 & -0.15 & 0.18 & -0.55 & 0.31 & 0.69 & 0.25 & 0.09 & -0.09 & 0.09 & -0.03 & -0.13 & -0.01 & 0.16 & -0.40 & 1.00\end{array}$

$\begin{array}{llllllllllllllllllllll}1.40 & 0.72 & 0.05 & 0.60 & 0.05 & 0.01 & -0.46 & 0.22 & 0.93 & 0.47 & 0.02 & -0.08 & 0.03 & -0.08 & -0.16 & -0.05 & 0.13 & -0.11 & 0.63 & 1.00\end{array}$

$18 \mathrm{~S}$ ate capacity

$\begin{array}{lllllllllllllllllllll}0.05 & 0.22 & -0.05 & -0.09 & -0.01 & 0.02 & 0.17 & -0.02 & -0.12 & -0.13 & 0.05 & 0.00 & -0.01 & 0.01 & 0.05 & 0.07 & 0.01 & 0.07 & -0.12 & -0.10 & 1.00\end{array}$

$\mathrm{N}=1,354$. Correlations with an absolute value of larger than 0.08 are significant at the $\mathrm{p}<0.05$ level.

This article is protected by copyright. All rights reserved. 
Table 2: Regression Models of PBC on State Acquirer

\begin{tabular}{|c|c|c|c|c|c|}
\hline $\begin{array}{l}\text { Model } \\
\text { Dependent Variable: }\end{array}$ & $\begin{array}{l}1 \\
\text { PBC }\end{array}$ & $\begin{array}{l}2 \\
\text { PBC }\end{array}$ & $\begin{array}{l}3 \\
\text { PBC }\end{array}$ & $\begin{array}{l}4 \\
\text { PBC }\end{array}$ & $\begin{array}{l}5 \\
\text { PBC }\end{array}$ \\
\hline GDP/capita & $\begin{array}{l}-0.017^{*} \\
(0.008)\end{array}$ & $\begin{array}{l}-0.017 * * \\
(0.008)\end{array}$ & $\begin{array}{l}-0.017 * * \\
(0.007)\end{array}$ & $\begin{array}{l}-0.017 * * \\
(0.008)\end{array}$ & $\begin{array}{l}-0.016^{*} \\
(0.009)\end{array}$ \\
\hline Stock market capitalization & $\begin{array}{l}-0.002 * * \\
(0.001)\end{array}$ & $\begin{array}{l}-0.002 * * \\
(0.001)\end{array}$ & $\begin{array}{l}-0.002 * * \\
(0.001)\end{array}$ & $\begin{array}{l}-0.002 * * \\
(0.001)\end{array}$ & $\begin{array}{l}-0.002 * * \\
(0.001)\end{array}$ \\
\hline Cheating on taxes & $\begin{array}{l}0.841 * * * \\
(0.223)\end{array}$ & $\begin{array}{l}0.850 * * * \\
(0.225)\end{array}$ & $\begin{array}{l}0.842 * * * \\
(0.205)\end{array}$ & $\begin{array}{l}0.825 * * * \\
(0.222)\end{array}$ & $\begin{array}{l}0.790 * * * \\
(0.225)\end{array}$ \\
\hline Freedom of press & $\begin{array}{l}-0.009 \\
(0.010)\end{array}$ & $\begin{array}{l}-0.008 \\
(0.010)\end{array}$ & $\begin{array}{l}-0.008 \\
(0.009)\end{array}$ & $\begin{array}{l}-0.008 \\
(0.010)\end{array}$ & $\begin{array}{l}-0.006 \\
(0.006)\end{array}$ \\
\hline Rule of law & $\begin{array}{c}0.017 \\
(0.044)\end{array}$ & $\begin{array}{l}0.016 \\
(0.044)\end{array}$ & $\begin{array}{l}0.015 \\
(0.046)\end{array}$ & $\begin{array}{l}0.015 \\
(0.045)\end{array}$ & $\begin{array}{l}-0.002 \\
(0.011)\end{array}$ \\
\hline Control of corruption & $\begin{array}{l}0.206 \\
(0.247)\end{array}$ & $\begin{array}{l}0.190 \\
(0.246)\end{array}$ & $\begin{array}{l}0.179 \\
(0.235)\end{array}$ & $\begin{array}{l}0.203 \\
(0.244)\end{array}$ & $\begin{array}{l}0.267 \\
(0.219)\end{array}$ \\
\hline Ex-post anti-self-dealing laws & $\begin{array}{l}-0.355 \\
(0.711)\end{array}$ & $\begin{array}{l}-0.418 \\
(0.706)\end{array}$ & $\begin{array}{l}-0.379 \\
(0.607)\end{array}$ & $\begin{array}{l}-0.386 \\
(0.712)\end{array}$ & $\begin{array}{l}-0.337 \\
(0.677)\end{array}$ \\
\hline Firm size & $\begin{array}{c}0.000 \\
(0.000)\end{array}$ & $\begin{array}{c}0.000 \\
(0.000)\end{array}$ & $\begin{array}{l}0.000 \\
(0.000)\end{array}$ & $\begin{array}{c}0.000 \\
(0.000)\end{array}$ & $\begin{array}{c}0.000 \\
(0.000)\end{array}$ \\
\hline R\&D spending & $\begin{array}{l}0.154^{* * *} \\
(0.055)\end{array}$ & $\begin{array}{l}0.151^{* * *} \\
(0.056)\end{array}$ & $\begin{array}{l}0.150 * * \\
(0.067)\end{array}$ & $\begin{array}{l}0.150^{* * *} \\
(0.056)\end{array}$ & $\begin{array}{l}0.154^{* * * *} \\
(0.057)\end{array}$ \\
\hline Financial leverage & $\begin{array}{l}-0.019 \\
(0.046)\end{array}$ & $\begin{array}{l}-0.019 \\
(0.045)\end{array}$ & $\begin{array}{l}-0.019 \\
(0.035)\end{array}$ & $\begin{array}{l}-0.016 \\
(0.045)\end{array}$ & $\begin{array}{l}-0.020 \\
(0.042)\end{array}$ \\
\hline Prior financial performance & $\begin{array}{l}0.002 * * * \\
(0.001)\end{array}$ & $\begin{array}{l}0.002 * * * \\
(0.001)\end{array}$ & $\begin{array}{l}0.002^{* * *} \\
(0.001)\end{array}$ & $\begin{array}{l}0.002^{* * *} \\
(0.001)\end{array}$ & $\begin{array}{l}0.002^{* * *} \\
(0.001)\end{array}$ \\
\hline Government sell-out & $\begin{array}{l}-0.415^{*} \\
(0.236)\end{array}$ & $\begin{array}{l}-0.406^{*} \\
(0.235)\end{array}$ & $\begin{array}{l}-0.413 \\
(0.278)\end{array}$ & $\begin{array}{l}-0.423^{*} \\
(0.238)\end{array}$ & $\begin{array}{l}-0.475^{*} \\
(0.246)\end{array}$ \\
\hline State minority control in target & $\begin{array}{l}0.788 * * * \\
(0.198)\end{array}$ & $\begin{array}{l}0.821 * * * \\
(0.185)\end{array}$ & $\begin{array}{l}0.790 * * * \\
(0.175)\end{array}$ & $\begin{array}{l}0.771 * * * \\
(0.207)\end{array}$ & $\begin{array}{l}0.876^{* * * *} \\
(0.203)\end{array}$ \\
\hline Foreign acquirer & $\begin{array}{c}0.237 \\
(0.181)\end{array}$ & $\begin{array}{c}0.241 \\
(0.180)\end{array}$ & $\begin{array}{c}0.236 \\
(0.206)\end{array}$ & $\begin{array}{c}0.224 \\
(0.180)\end{array}$ & $\begin{array}{c}0.222 \\
(0.166)\end{array}$ \\
\hline Ex-ante anti-self-dealing laws & $\begin{array}{l}-0.505 \\
(0.312)\end{array}$ & $\begin{array}{l}-0.502 \\
(0.312)\end{array}$ & $\begin{array}{l}-0.452 \\
(0.375)\end{array}$ & $\begin{array}{l}-0.490 \\
(0.311)\end{array}$ & $\begin{array}{l}-0.562^{*} \\
(0.334)\end{array}$ \\
\hline Political constraints & $\begin{array}{l}-0.347 \\
(0.518)\end{array}$ & $\begin{array}{l}-0.353 \\
(0.523)\end{array}$ & $\begin{array}{l}-0.342 \\
(0.360)\end{array}$ & $\begin{array}{l}-0.430 \\
(0.533)\end{array}$ & $\begin{array}{l}-0.166 \\
(0.528)\end{array}$ \\
\hline State Capacity & $\begin{array}{c}0.007 \\
(0.301)\end{array}$ & $\begin{array}{c}0.039 \\
(0.303)\end{array}$ & $\begin{array}{c}0.051 \\
(0.320)\end{array}$ & $\begin{array}{l}0.028 \\
(0.300)\end{array}$ & $\begin{array}{l}-0.097 \\
(0.286)\end{array}$ \\
\hline Hypotheses Testing & & & & & \\
\hline State acquirer & & $\begin{array}{l}-0.531 * * \\
(0.265)\end{array}$ & $\begin{array}{c}0.285 \\
(0.388)\end{array}$ & $\begin{array}{l}-1.177 * * * \\
(0.398)\end{array}$ & $\begin{array}{l}-1.247 * * * \\
(0.298)\end{array}$ \\
\hline State acquirer X Ex-ante anti-self-dealing laws & & & $\begin{array}{l}-1.114 * * \\
(0.544)\end{array}$ & & \\
\hline State acquirer X Political constraints & & & & $\begin{array}{l}1.641^{* *} \\
(0.668)\end{array}$ & \\
\hline State acquirer X State Capacity & & & & & $\begin{array}{l}0.661 * * \\
(0.306)\end{array}$ \\
\hline Constant & $\begin{array}{l}-1.062 \\
(1.282)\end{array}$ & $\begin{array}{l}-1.031 \\
(1.281)\end{array}$ & $\begin{array}{l}-1.118 \\
(0.970)\end{array}$ & $\begin{array}{l}-0.994 \\
(1.287)\end{array}$ & $\begin{array}{l}-0.430 \\
(0.769)\end{array}$ \\
\hline Number of Countries & 54 & 54 & 54 & 54 & 54 \\
\hline Number of Transactions & 1,354 & 1,354 & 1,354 & 1,354 & 1,354 \\
\hline
\end{tabular}


$\mathrm{R}^{2}$

0.100

0.105

0.109

0.110

0.108

Robust standard errors in parentheses; Standard errors clustered on country level; Year and industry effects are included but not reported. $* \mathrm{p}<0.10,{ }^{* *} \mathrm{p}<0.05,{ }^{* * *} \mathrm{p}<0.01$ 
Table 3: Regression Models based on CEM Sample

\begin{tabular}{|c|c|c|c|c|c|}
\hline $\begin{array}{l}\text { Model } \\
\text { Dependent Variable: }\end{array}$ & $\begin{array}{l}1 \\
\text { PBC }\end{array}$ & $\begin{array}{l}2 \\
\text { PBC }\end{array}$ & $\begin{array}{l}3 \\
\text { PBC }\end{array}$ & $\begin{array}{l}4 \\
\text { PBC }\end{array}$ & $\begin{array}{l}5 \\
\text { PBC }\end{array}$ \\
\hline GDP/capita & $\begin{array}{l}-0.016^{*} \\
(0.008)\end{array}$ & $\begin{array}{l}-0.016^{*} \\
(0.008)\end{array}$ & $\begin{array}{l}-0.016^{* *} \\
(0.007)\end{array}$ & $\begin{array}{l}-0.016^{*} \\
(0.008)\end{array}$ & $\begin{array}{l}-0.015 \\
(0.009)\end{array}$ \\
\hline Stock market capitalization & $\begin{array}{l}-0.002 * \\
(0.001)\end{array}$ & $\begin{array}{l}-0.002 * \\
(0.001)\end{array}$ & $\begin{array}{l}-0.002 * * \\
(0.001)\end{array}$ & $\begin{array}{l}-0.002 * \\
(0.001)\end{array}$ & $\begin{array}{l}-0.002^{*} \\
(0.001)\end{array}$ \\
\hline Cheating on taxes & $\begin{array}{l}0.805^{* * *} \\
(0.215)\end{array}$ & $\begin{array}{l}0.813^{* * *} \\
(0.216)\end{array}$ & $\begin{array}{l}0.805^{* * *} \\
(0.195)\end{array}$ & $\begin{array}{l}0.786^{* * *} \\
(0.214)\end{array}$ & $\begin{array}{l}0.750 * * * \\
(0.217)\end{array}$ \\
\hline Freedom of press & $\begin{array}{l}-0.009 \\
(0.010)\end{array}$ & $\begin{array}{l}-0.009 \\
(0.010)\end{array}$ & $\begin{array}{l}-0.009 \\
(0.009)\end{array}$ & $\begin{array}{l}-0.008 \\
(0.010)\end{array}$ & $\begin{array}{l}-0.006 \\
(0.006)\end{array}$ \\
\hline Rule of law & $\begin{array}{c}0.013 \\
(0.043)\end{array}$ & $\begin{array}{c}0.012 \\
(0.044)\end{array}$ & $\begin{array}{c}0.011 \\
(0.046)\end{array}$ & $\begin{array}{c}0.011 \\
(0.044)\end{array}$ & $\begin{array}{l}-0.004 \\
(0.011)\end{array}$ \\
\hline Control of corruption & $\begin{array}{c}0.171 \\
(0.247)\end{array}$ & $\begin{array}{l}0.155 \\
(0.246)\end{array}$ & $\begin{array}{c}0.144 \\
(0.246)\end{array}$ & $\begin{array}{c}0.172 \\
(0.243)\end{array}$ & $\begin{array}{c}0.236 \\
(0.226)\end{array}$ \\
\hline Ex-post anti-self-dealing laws & $\begin{array}{l}-0.150 \\
(0.687)\end{array}$ & $\begin{array}{l}-0.210 \\
(0.681)\end{array}$ & $\begin{array}{l}-0.176 \\
(0.587)\end{array}$ & $\begin{array}{l}-0.184 \\
(0.687)\end{array}$ & $\begin{array}{l}-0.153 \\
(0.674)\end{array}$ \\
\hline Firm size & $\begin{array}{r}0.001^{*} \\
(0.000)\end{array}$ & $\begin{array}{r}0.001^{*} \\
(0.000)\end{array}$ & $\begin{array}{c}0.001 * \\
(0.000)\end{array}$ & $\begin{array}{r}0.001^{*} \\
(0.000)\end{array}$ & $\begin{array}{c}0.000 \\
(0.000)\end{array}$ \\
\hline R\&D spending & $\begin{array}{l}0.172 * * * \\
(0.058)\end{array}$ & $\begin{array}{l}0.169^{* * *} \\
(0.058)\end{array}$ & $\begin{array}{l}0.168 * * \\
(0.071)\end{array}$ & $\begin{array}{l}0.169 * * * \\
(0.058)\end{array}$ & $\begin{array}{l}0.164 * * * \\
(0.060)\end{array}$ \\
\hline Financial leverage & $\begin{array}{l}-0.032 \\
(0.047)\end{array}$ & $\begin{array}{l}-0.032 \\
(0.046)\end{array}$ & $\begin{array}{l}-0.032 \\
(0.035)\end{array}$ & $\begin{array}{l}-0.029 \\
(0.046)\end{array}$ & $\begin{array}{l}-0.028 \\
(0.044)\end{array}$ \\
\hline Prior financial performance & $\begin{array}{l}0.008 * * \\
(0.003)\end{array}$ & $\begin{array}{l}0.008 * * \\
(0.003)\end{array}$ & $\begin{array}{l}0.008 * * \\
(0.003)\end{array}$ & $\begin{array}{l}0.008 * * \\
(0.003)\end{array}$ & $\begin{array}{r}0.007^{*} \\
(0.003)\end{array}$ \\
\hline Government sell-out & $\begin{array}{l}-0.412^{*} \\
(0.236)\end{array}$ & $\begin{array}{l}-0.403^{*} \\
(0.235)\end{array}$ & $\begin{array}{l}-0.410 \\
(0.273)\end{array}$ & $\begin{array}{l}-0.420^{*} \\
(0.238)\end{array}$ & $\begin{array}{l}-0.457^{*} \\
(0.246)\end{array}$ \\
\hline State minority control in target & $\begin{array}{l}0.768 * * * \\
(0.255)\end{array}$ & $\begin{array}{l}0.808^{* * *} \\
(0.240)\end{array}$ & $\begin{array}{l}0.775^{* * *} \\
(0.191)\end{array}$ & $\begin{array}{l}0.759 * * * \\
(0.262)\end{array}$ & $\begin{array}{l}0.901 * * * \\
(0.256)\end{array}$ \\
\hline Foreign acquirer & $\begin{array}{c}0.221 \\
(0.181)\end{array}$ & $\begin{array}{c}0.224 \\
(0.180)\end{array}$ & $\begin{array}{c}0.220 \\
(0.198)\end{array}$ & $\begin{array}{c}0.208 \\
(0.179)\end{array}$ & $\begin{array}{c}0.199 \\
(0.171)\end{array}$ \\
\hline Ex-ante anti-self-dealing laws & $\begin{array}{l}-0.537^{*} \\
(0.319)\end{array}$ & $\begin{array}{l}-0.533 \\
(0.320)\end{array}$ & $\begin{array}{l}-0.484 \\
(0.385)\end{array}$ & $\begin{array}{l}-0.523 \\
(0.320)\end{array}$ & $\begin{array}{l}-0.609^{*} \\
(0.333)\end{array}$ \\
\hline Political constraints & $\begin{array}{l}-0.347 \\
(0.523)\end{array}$ & $\begin{array}{l}-0.345 \\
(0.528)\end{array}$ & $\begin{array}{l}-0.334 \\
(0.376)\end{array}$ & $\begin{array}{l}-0.418 \\
(0.537)\end{array}$ & $\begin{array}{l}-0.132 \\
(0.541)\end{array}$ \\
\hline State Capacity & $\begin{array}{c}0.035 \\
(0.302)\end{array}$ & $\begin{array}{c}0.066 \\
(0.304)\end{array}$ & $\begin{array}{c}0.079 \\
(0.327)\end{array}$ & $\begin{array}{c}0.053 \\
(0.301)\end{array}$ & $\begin{array}{l}-0.062 \\
(0.300)\end{array}$ \\
\hline Hypotheses Testing & & & & & \\
\hline State acquirer & & $\begin{array}{l}-0.525^{*} \\
(0.270)\end{array}$ & $\begin{array}{c}0.231 \\
(0.411)\end{array}$ & $\begin{array}{l}-1.214 * * * \\
(0.403)\end{array}$ & $\begin{array}{l}-1.264 * * * \\
(0.314)\end{array}$ \\
\hline State acquirer X Ex-ante anti-self-dealing laws & & & $\begin{array}{l}-1.068^{*} \\
(0.576)\end{array}$ & & \\
\hline State acquirer X Political constraints & & & & $\begin{array}{l}1.655^{* *} \\
(0.651)\end{array}$ & \\
\hline State acquirer X State Capacity & & & & & $\begin{array}{l}0.674 * * \\
(0.309)\end{array}$ \\
\hline Constant & $\begin{array}{l}-1.176 \\
(1.231)\end{array}$ & $\begin{array}{l}-1.155 \\
(1.228)\end{array}$ & $\begin{array}{l}-1.233 \\
(0.909)\end{array}$ & $\begin{array}{l}-1.110 \\
(1.234)\end{array}$ & $\begin{array}{l}-0.525 \\
(0.729)\end{array}$ \\
\hline Number of Countries & 54 & 54 & 54 & 54 & 54 \\
\hline Number of Transactions & 1,319 & 1,319 & 1,319 & 1,319 & 1,319 \\
\hline
\end{tabular}


$\mathrm{R}^{2}$

0.104

0.107

0.110

0.111

0.112

Robust standard errors in parentheses; Standard errors clustered on country level; Year and industry effects are included but not reported. $* \mathrm{p}<0.10,{ }^{* *} \mathrm{p}<0.05,{ }^{* * *} \mathrm{p}<0.01$ 
Table 4: Regression Models Split Sample between Domestic and Foreign Acquisitions

\begin{tabular}{|c|c|c|c|c|c|c|c|c|c|c|}
\hline $\begin{array}{l}\text { Model } \\
\text { Dependent Variable: }\end{array}$ & $\begin{array}{l}1 \\
\text { Domestic } \\
\text { PBC }\end{array}$ & $\begin{array}{l}2 \\
\text { Domestic } \\
\text { PBC }\end{array}$ & $\begin{array}{l}3 \\
\text { Domestic } \\
\text { PBC }\end{array}$ & $\begin{array}{l}4 \\
\text { Domestic } \\
\text { PBC }\end{array}$ & $\begin{array}{l}5 \\
\text { Domestic } \\
\text { PBC }\end{array}$ & $\begin{array}{l}6 \\
\text { Foreign } \\
\text { PBC }\end{array}$ & $\begin{array}{l}7 \\
\text { Foreign } \\
\text { PBC }\end{array}$ & $\begin{array}{l}8 \\
\text { Foreign } \\
\text { PBC }\end{array}$ & $\begin{array}{l}9 \\
\text { Foreign } \\
\text { PBC }\end{array}$ & $\begin{array}{l}10 \\
\text { Foreign } \\
\text { PBC }\end{array}$ \\
\hline GDP/capita & $\begin{array}{l}-0.018 \\
(0.017)\end{array}$ & $\begin{array}{l}-0.019 \\
(0.017)\end{array}$ & $\begin{array}{l}-0.019 \\
(0.017)\end{array}$ & $\begin{array}{l}-0.019 \\
(0.017)\end{array}$ & $\begin{array}{l}-0.025 \\
(0.017)\end{array}$ & $\begin{array}{l}-0.029 \\
(0.020)\end{array}$ & $\begin{array}{l}-0.030 \\
(0.020)\end{array}$ & $\begin{array}{l}-0.029 \\
(0.017)\end{array}$ & $\begin{array}{l}-0.029 \\
(0.020)\end{array}$ & $\begin{array}{l}-0.022 \\
(0.016)\end{array}$ \\
\hline Stock market capitalization & $\begin{array}{l}-0.003 * * \\
(0.001)\end{array}$ & $\begin{array}{l}-0.002^{* *} \\
(0.001)\end{array}$ & $\begin{array}{l}-0.002^{* *} \\
(0.001)\end{array}$ & $\begin{array}{l}-0.002 * * \\
(0.001)\end{array}$ & $\begin{array}{l}-0.003^{* * *} \\
(0.001)\end{array}$ & $\begin{array}{l}-0.002 \\
(0.002)\end{array}$ & $\begin{array}{l}-0.002 \\
(0.002)\end{array}$ & $\begin{array}{l}-0.003 \\
(0.003)\end{array}$ & $\begin{array}{l}-0.003 \\
(0.002)\end{array}$ & $\begin{array}{l}-0.001 \\
(0.002)\end{array}$ \\
\hline Cheating on taxes & $\begin{array}{l}0.542^{* * * *} \\
(0.164)\end{array}$ & $\begin{array}{l}0.551^{* * * *} \\
(0.164)\end{array}$ & $\begin{array}{l}0.543^{* * * *} \\
(0.160)\end{array}$ & $\begin{array}{l}0.530^{* * * *} \\
(0.162)\end{array}$ & $\begin{array}{l}0.504^{* *} \\
(0.201)\end{array}$ & $\begin{array}{c}0.374 \\
(0.289)\end{array}$ & $\begin{array}{c}0.376 \\
(0.291)\end{array}$ & $\begin{array}{c}0.369 \\
(0.288)\end{array}$ & $\begin{array}{c}0.163 \\
(0.250)\end{array}$ & $\begin{array}{c}0.490 \\
(0.291)\end{array}$ \\
\hline Freedom of press & $\begin{array}{l}-0.007 \\
(0.017)\end{array}$ & $\begin{array}{l}-0.005 \\
(0.017)\end{array}$ & $\begin{array}{l}-0.005 \\
(0.017)\end{array}$ & $\begin{array}{l}-0.005 \\
(0.017)\end{array}$ & $\begin{array}{l}-0.008 \\
(0.006)\end{array}$ & $\begin{array}{l}-0.004 \\
(0.018)\end{array}$ & $\begin{array}{l}-0.004 \\
(0.018)\end{array}$ & $\begin{array}{l}-0.002 \\
(0.012)\end{array}$ & $\begin{array}{l}-0.006 \\
(0.017)\end{array}$ & $\begin{array}{c}0.003 \\
(0.004)\end{array}$ \\
\hline Rule of law & $\begin{array}{c}0.053 \\
(0.071)\end{array}$ & $\begin{array}{c}0.054 \\
(0.073)\end{array}$ & $\begin{array}{c}0.053 \\
(0.074)\end{array}$ & $\begin{array}{c}0.051 \\
(0.072)\end{array}$ & $\begin{array}{c}0.004 \\
(0.020)\end{array}$ & $\begin{array}{l}-0.039 \\
(0.106)\end{array}$ & $\begin{array}{l}-0.037 \\
(0.103)\end{array}$ & $\begin{array}{l}-0.029 \\
(0.064)\end{array}$ & $\begin{array}{l}-0.039 \\
(0.097)\end{array}$ & $\begin{array}{c}0.001 \\
(0.029)\end{array}$ \\
\hline Control of corruption & $\begin{array}{l}-0.041 \\
(0.182)\end{array}$ & $\begin{array}{l}-0.052 \\
(0.180)\end{array}$ & $\begin{array}{l}-0.050 \\
(0.179)\end{array}$ & $\begin{array}{l}-0.027 \\
(0.174)\end{array}$ & $\begin{array}{c}0.055 \\
(0.218)\end{array}$ & $\begin{array}{c}0.451 \\
(0.287)\end{array}$ & $\begin{array}{c}0.440 \\
(0.284)\end{array}$ & $\begin{array}{c}0.437^{*} \\
(0.237)\end{array}$ & $\begin{array}{c}0.474 \\
(0.290)\end{array}$ & $\begin{array}{l}0.441^{* *} \\
(0.200)\end{array}$ \\
\hline Ex-post anti-self-dealing laws & $\begin{array}{l}-0.379 \\
(0.967)\end{array}$ & $\begin{array}{l}-0.483 \\
(0.972)\end{array}$ & $\begin{array}{l}-0.468 \\
(0.981)\end{array}$ & $\begin{array}{l}-0.405 \\
(0.982)\end{array}$ & $\begin{array}{l}-0.359 \\
(1.027)\end{array}$ & $\begin{array}{l}-0.648 \\
(1.308)\end{array}$ & $\begin{array}{l}-0.674 \\
(1.284)\end{array}$ & $\begin{array}{l}-0.408 \\
(1.023)\end{array}$ & $\begin{array}{l}-0.475 \\
(1.292)\end{array}$ & $\begin{array}{l}-0.881 \\
(1.176)\end{array}$ \\
\hline Firm size & $\begin{array}{l}-0.000 \\
(0.000)\end{array}$ & $\begin{array}{l}-0.000 \\
(0.000)\end{array}$ & $\begin{array}{l}-0.000 \\
(0.000)\end{array}$ & $\begin{array}{l}-0.000 \\
(0.000)\end{array}$ & $\begin{array}{l}-0.000 \\
(0.000)\end{array}$ & $\begin{array}{c}0.000 \\
(0.000)\end{array}$ & $\begin{array}{c}0.000 \\
(0.000)\end{array}$ & $\begin{array}{c}0.000 \\
(0.000)\end{array}$ & $\begin{array}{c}0.000 \\
(0.000)\end{array}$ & $\begin{array}{c}0.000 \\
(0.000)\end{array}$ \\
\hline$R \& D$ spending & $\begin{array}{l}0.288^{* * *} \\
(0.135)\end{array}$ & $\begin{array}{l}0.285^{* *} \\
(0.135)\end{array}$ & $\begin{array}{l}0.284^{* *} \\
(0.135)\end{array}$ & $\begin{array}{l}0.284 * * \\
(0.134)\end{array}$ & $\begin{array}{l}0.284^{* *} \\
(0.136)\end{array}$ & $\begin{array}{c}0.142 \\
(0.141)\end{array}$ & $\begin{array}{c}0.141 \\
(0.144)\end{array}$ & $\begin{array}{c}0.158 \\
(0.163)\end{array}$ & $\begin{array}{c}0.155 \\
(0.162)\end{array}$ & $\begin{array}{c}0.116 \\
(0.125)\end{array}$ \\
\hline Financial leverage & $\begin{array}{c}0.023 \\
(0.059)\end{array}$ & $\begin{array}{c}0.022 \\
(0.058)\end{array}$ & $\begin{array}{c}0.023 \\
(0.058)\end{array}$ & $\begin{array}{c}0.025 \\
(0.058)\end{array}$ & $\begin{array}{c}0.015 \\
(0.057)\end{array}$ & $\begin{array}{l}-0.050 \\
(0.054)\end{array}$ & $\begin{array}{l}-0.049 \\
(0.054)\end{array}$ & $\begin{array}{l}-0.048 \\
(0.061)\end{array}$ & $\begin{array}{l}-0.079 \\
(0.065)\end{array}$ & $\begin{array}{l}-0.019 \\
(0.050)\end{array}$ \\
\hline Prior financial performance & $\begin{array}{l}0.003^{* * *} \\
(0.001)\end{array}$ & $\begin{array}{l}0.003^{* * * *} \\
(0.001)\end{array}$ & $\begin{array}{l}0.003^{* * *} \\
(0.001)\end{array}$ & $\begin{array}{l}0.003^{* * * *} \\
(0.001)\end{array}$ & $\begin{array}{l}0.003 * * * \\
(0.001)\end{array}$ & $\begin{array}{c}0.000 \\
(0.000)\end{array}$ & $\begin{array}{c}0.000 \\
(0.000)\end{array}$ & $\begin{array}{c}0.000 \\
(0.000)\end{array}$ & $\begin{array}{l}-0.000 \\
(0.000)\end{array}$ & $\begin{array}{c}0.000 \\
(0.000)\end{array}$ \\
\hline Government sell-out & $\begin{array}{l}-0.949^{*} \\
(0.515)\end{array}$ & $\begin{array}{l}-0.949^{*} \\
(0.508)\end{array}$ & $\begin{array}{l}-0.957^{*} \\
(0.511)\end{array}$ & $\begin{array}{l}-0.958^{*} \\
(0.513)\end{array}$ & $\begin{array}{l}-0.901^{*} \\
(0.449)\end{array}$ & $\begin{array}{l}-0.164 \\
(0.809)\end{array}$ & $\begin{array}{l}-0.134 \\
(0.824)\end{array}$ & $\begin{array}{l}-0.154 \\
(1.183)\end{array}$ & $\begin{array}{l}-0.345 \\
(0.732)\end{array}$ & $\begin{array}{l}-0.441 \\
(0.849)\end{array}$ \\
\hline State minority control in target & $\begin{array}{l}0.839^{* * * *} \\
(0.151)\end{array}$ & $\begin{array}{l}0.879 * * * \\
(0.143)\end{array}$ & $\begin{array}{l}0.834^{* * * *} \\
(0.158)\end{array}$ & $\begin{array}{l}0.823^{* * * *} \\
(0.156)\end{array}$ & $\begin{array}{l}0.956^{* * *} \\
(0.184)\end{array}$ & $\begin{array}{l}0.889^{* *} \\
(0.410)\end{array}$ & $\begin{array}{l}0.914^{* *} \\
(0.389)\end{array}$ & $\begin{array}{l}1.005^{* *} \\
(0.445)\end{array}$ & $\begin{array}{c}0.816 \\
(0.525)\end{array}$ & $\begin{array}{l}0.939^{*} \\
(0.503)\end{array}$ \\
\hline Ex-ante anti-self-dealing laws & $\begin{array}{l}-0.154 \\
(0.503)\end{array}$ & $\begin{array}{l}-0.147 \\
(0.498)\end{array}$ & $\begin{array}{l}-0.117 \\
(0.502)\end{array}$ & $\begin{array}{l}-0.142 \\
(0.498)\end{array}$ & $\begin{array}{l}-0.285 \\
(0.467)\end{array}$ & $\begin{array}{l}-0.766 \\
(0.751)\end{array}$ & $\begin{array}{l}-0.764 \\
(0.749)\end{array}$ & $\begin{array}{l}-0.593 \\
(0.577)\end{array}$ & $\begin{array}{l}-0.555 \\
(0.710)\end{array}$ & $\begin{array}{l}-0.698 \\
(0.660)\end{array}$ \\
\hline Political constraints & $\begin{array}{c}0.013 \\
(0.589)\end{array}$ & $\begin{array}{c}0.032 \\
(0.582)\end{array}$ & $\begin{array}{c}0.040 \\
(0.582)\end{array}$ & $\begin{array}{l}-0.058 \\
(0.568)\end{array}$ & $\begin{array}{c}0.123 \\
(0.559)\end{array}$ & $\begin{array}{c}0.046 \\
(0.668)\end{array}$ & $\begin{array}{c}0.057 \\
(0.685)\end{array}$ & $\begin{array}{c}0.134 \\
(0.658)\end{array}$ & $\begin{array}{c}0.025 \\
(0.629)\end{array}$ & $\begin{array}{l}-0.251 \\
(0.779)\end{array}$ \\
\hline State Capacity & $\begin{array}{c}0.402 \\
(0.553)\end{array}$ & $\begin{array}{c}0.446 \\
(0.554)\end{array}$ & $\begin{array}{c}0.441 \\
(0.556)\end{array}$ & $\begin{array}{c}0.413 \\
(0.549)\end{array}$ & $\begin{array}{c}0.452 \\
(0.526)\end{array}$ & $\begin{array}{l}-0.321 \\
(0.596)\end{array}$ & $\begin{array}{l}-0.295 \\
(0.601)\end{array}$ & $\begin{array}{l}-0.358 \\
(0.509)\end{array}$ & $\begin{array}{l}-0.311 \\
(0.587)\end{array}$ & $\begin{array}{l}-0.400 \\
(0.466)\end{array}$ \\
\hline $\begin{array}{l}\text { Hypotheses Testing } \\
\text { State acquirer }\end{array}$ & & $\begin{array}{l}-0.562 * * * \\
(0.199)\end{array}$ & $\begin{array}{c}0.050 \\
(0.641)\end{array}$ & $\begin{array}{l}-0.905^{* * *} \\
(0.284)\end{array}$ & $\begin{array}{l}-2.024 * * * \\
(0.454)\end{array}$ & & $\begin{array}{l}-0.373 \\
(0.727)\end{array}$ & $\begin{array}{c}1.243 \\
(0.825)\end{array}$ & $\begin{array}{l}-2.832 \\
(3.220)\end{array}$ & $\begin{array}{c}1.328 \\
(1.990)\end{array}$ \\
\hline State acquirer X Ex-ante anti-self-dealing laws & & & $\begin{array}{l}-0.754^{*} \\
(0.370)\end{array}$ & & & & & $\begin{array}{l}-2.832^{* *} \\
(1.236)\end{array}$ & & \\
\hline State acquirer X Political constraints & & & & $\begin{array}{l}1.361^{* *} \\
(0.540)\end{array}$ & & & & & $\begin{array}{c}3.583 \\
(2.260)\end{array}$ & \\
\hline State acquirer X State Capacity & & & & & $\begin{array}{l}1.286^{* * *} \\
(0.292)\end{array}$ & & & & & $\begin{array}{l}-1.023 \\
(1.288)\end{array}$ \\
\hline Constant & $\begin{array}{l}-0.878 \\
(1.209)\end{array}$ & $\begin{array}{l}-0.902 \\
(1.202)\end{array}$ & $\begin{array}{l}-0.921 \\
(1.204)\end{array}$ & $\begin{array}{l}-0.846 \\
(1.179)\end{array}$ & $\begin{array}{l}-0.974 \\
(0.970)\end{array}$ & $\begin{array}{c}0.499 \\
(1.367)\end{array}$ & $\begin{array}{c}0.508 \\
(1.382)\end{array}$ & $\begin{array}{c}0.120 \\
(1.048)\end{array}$ & $\begin{array}{c}0.993 \\
(1.294)\end{array}$ & $\begin{array}{c}1.263 \\
(1.183)\end{array}$ \\
\hline
\end{tabular}

This article is protected by copyright. All rights reserved. 
Number of Countries

Number of Transactions

$\begin{array}{ll}49 & 49 \\ 948 & 948\end{array}$

\begin{tabular}{ll}
49 & 49 \\
948 & 948 \\
0.131 & 0.133 \\
\hline
\end{tabular}

\begin{tabular}{ll}
948 & 49 \\
0.133 & 948 \\
\hline
\end{tabular}

49
948

47
406

$\begin{array}{ll}47 & 47 \\ 406 & 406\end{array}$

$\begin{array}{ll}47 & 47 \\ 406 & 406\end{array}$

Robust standard errors in parentheses; Standard errors clustered on country level; Year and industry effects are included but not reported. * $\mathrm{p}<0.10, * * \mathrm{p}<0.05$ $* * * \mathrm{p}<0.01$ 
Figure 1: Interaction Graphs

Panel A: State Acquirer Interaction with Anti Self-Dealing Laws Panel B: State Acquirer Interaction with POLCON
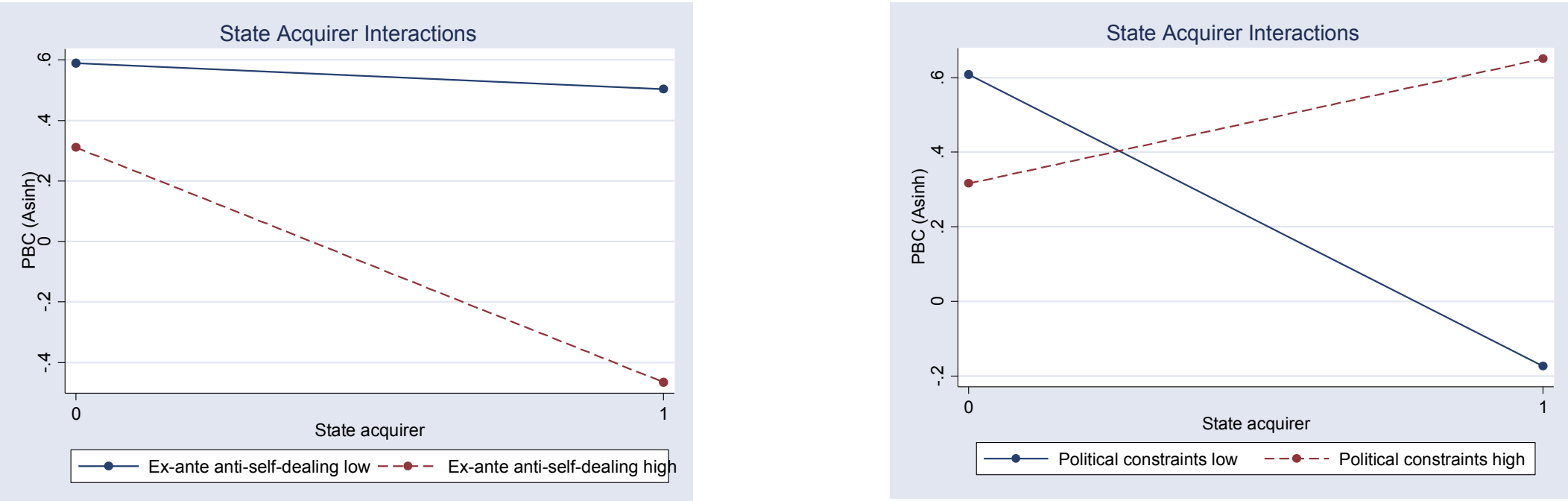

This article is protected by copyright. All rights reserved. 


\section{Panel C: State Acquirer Interaction with State Capacity}

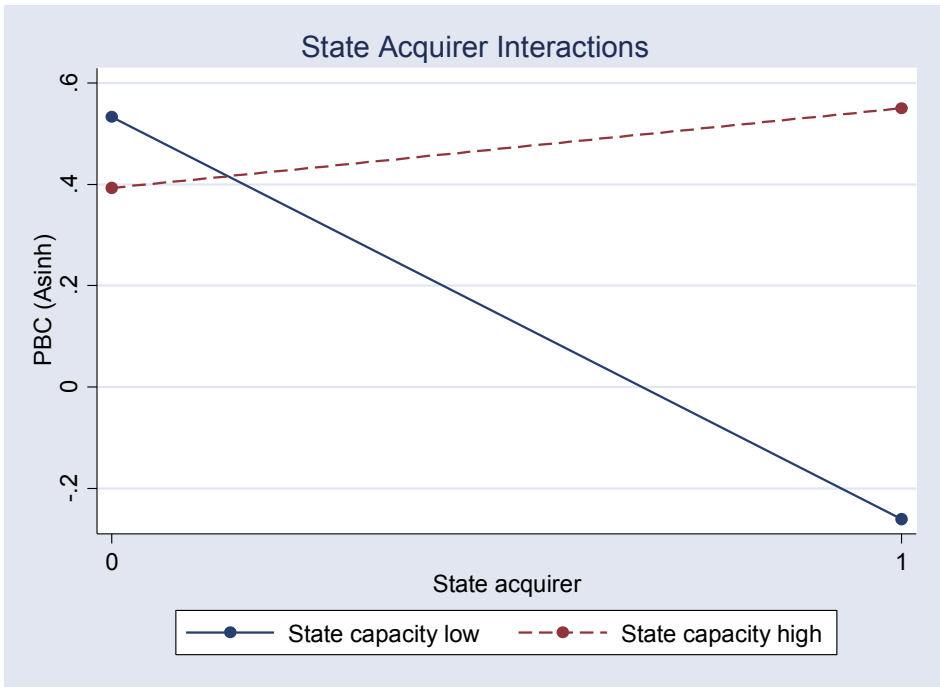

This article is protected by copyright. All rights reserved. 